\title{
A Tale of Two States: Asymmetries in the UK Small, Value and Momentum Premiums
}

\author{
Golam Sarwar ${ }^{\mathrm{a}}$, \\ Cesario Mateus ${ }^{\mathrm{a}}$, \\ Natasa Todorovic ${ }^{\mathrm{b} *}$ \\ ${ }^{a}$ University of Greenwich, London, $U K$ \\ ${ }^{b}$ The Centre for Asset Management Research, \\ Cass Business School, City University, London, UK
}

\begin{abstract}
This paper performs comparative analysis of the asymmetries in size, value and momentum premium and their macroeconomic determinants over the UK economic cycles, using Markov switching approach. We associate Markov switching regime 1 with economic upturn and regime 2 with economic downturn. We find clear evidence of cyclical variations in the three premiums, most notable being that in the size premium, which changes from positive in expansions to negative in recessions. Macroeconomic indicators prompting such cyclicality the most are variables that proxy credit market conditions, namely the interest rates, term structure and credit spread. Overall, macro factors tend to have more significant impact on the three premiums during economic downturns. The results are robust to the choice of information variable used in modelling transition probabilities of the two-stage Markov switching model. We show that exploiting cyclicality in premiums proves particularly profitable for portfolios featuring small cap stocks in recessions at a feasible level of transaction costs.
\end{abstract}

JEL classification: G11, E32

Key words: Size, Value and Momentum premiums, Two-state Markov switching model, Macroeconomic determinants, Cyclicality

*Corresponding author. Tel.: +44 207040 0120. E-mail addresses: g.sarwar@greenwich.ac.uk (Sarwar), c.mateus@greenwich.ac.uk (Mateus), n.todorovic@city.ac.uk (Todorovic). 


\section{Introduction}

Since Fama-French (1993) and Carhart (1997) related a small cap premium (small-minus-big company returns (SMB)), value premium (high book to market minus low book to market ratio stock returns (HML)) and momentum premium (winner or up-momentum minus loser or down-momentum stock returns (UMD)) to excess returns, a vast body of literature that analyses determinants of those premiums has emerged. While, for instance, De Bondt \& Thaler (1985) and Daniel, Hirshleifer, \& Subrahmanyam (1998) argue that the value premium arises due to the overreaction of investors, a number of academic studies points that the value and size premium are proxies for some non-diversifiable risks not captured by the standard CAPM model, such as risks resulting from variations in macroeconomic factors (see Kelly, 2003; Liew \& Vassalou, 2000; Petkova, 2006; Vassalou, 2003; Zhang et al. 2009; Black and McMillan, 2005; Gulen Xing, \& Zhang, 2008, Kim et al., 2014 and Perez-Quiros \& Timmermann, 2000). The literature on variety of macroeconomic sources that can cause asymmetries in expected returns of value, small cap and winner portfolios over different phases of economic cycle focuses on the US market. We expand this literature by investigating the determinants of the cyclical variations in size, value and momentum premiums in the UK. UK asset management industry accounts for more than one third (37\%) of European assets under management and it is globally second only to US. 39\% percent of those assets are managed on behalf of the overseas clients and $32 \%$ of all equity mandates are placed in the UK equity ${ }^{1}$. Therefore, we believe that examining cyclicality of premiums in the UK market is of interest to investors and asset managers domiciled both in the UK and overseas. To the best of our knowledge this is the first comprehensive study of the asymmetry of the three premiums in the UK, which scrutinizes the relative differences in the cyclical behaviour of the three premiums and their macroeconomic determinants. Last but not least, our study is the first that encompasses the period of the recent global financial crisis.

Let us first take a look at the existing evidence on how small, value and momentum premiums in the US market are affected by different economic conditions. We will also review why small, value and loser firms may be more sensitive when it comes to recessionary shocks than their counterparts. Research focusing on cyclical asymmetries in small and large size firms reveals that their sources of finance are different, implying they should not be affected in the same manner by the credit market constraints. Perez-Quiros \& Timmermann

\footnotetext{
${ }^{1}$ The Investment Association Annual Survey 'Asset Management in the UK' available from: http://www.theinvestmentassociation.org//assets/files/research/2015/20150914-ams2014-2015-fullsurvey.pdf
} 
(2000) argue that worsening credit market conditions in the US during economic downturns have an adverse effect on the small cap firms, suggesting greater risk and increase in the risk premium. Chan \& Chen (1991) prove that characteristics of a firm rather than its size matter for the US size premium. Specifically, they find a large proportion of marginal firms (with lower production efficiency and higher financial leverage) in the small cap portfolio. Since marginal firms have low price, while having higher financial leverage and cash flow problems; their price tends to be more sensitive to the changes in market conditions. Similar is confirmed more recently by Kim \& Burnie (2002). This evidence implies that one should expect small cap premium to differ across economic states.

As far as asymmetry in value premium is concerned, the US evidence shows that value portfolio returns respond more to the changes of interest rates and money supply over the recessionary period than expansionary period, supporting the asymmetric behaviour hypothesis (see Black and McMillan, 2005). Three distinct sources, namely, costly reversibility, operating leverage and financial leverage have been identified as the sources of relative inflexibility of value firms in mitigating recessionary shocks. Hence, these firms are riskier in recessions leading to higher expected value premiums. First, costly reversibility implies there is higher cost of firms' to reduce the scale of productive assets than it is to expand. Value firms want to disinvest more in economic downturn because their assets are less profitable than those of growth firms; such disinvesting is less important for growth firms (Gulen et al., 2008). Since disinvesting is restricted by costly reversibility, the fundamentals of value firms are affected more severely than the fundamentals of growth firms in economic downturn when the credit market conditions are unfavourable. In similar spirit, Gala(2005)argues that investment irreversibility plays a vital role in explaining the size effects in stock returns and their relation to risk and firms' fundamentals. Second, in recessions, the stock prices and revenues of value firms fall more relative to book values and average market level, respectively, so the value firms ought to have higher operating leverage than growth firms. The operating leverage will have adverse effect on value firm by the negative aggregate shocks during economic downturn as suggested by Gulen et al. (2008). Third, Livdan, Sapriza, \& Zhang (2009) find that value firms are characterized with higher financial leverage and investors require higher expected returns to hold higher levered stocks during economic downturn when the value firms are more exposed to the financial constraints. All this evidence is pointing that a higher value premium should be expected in recessions compared to expansions. 
Looking at the variations in momentum returns across economic states, Kim et al. (2014) suggest that winner stocks are more impacted in economic expansions while loser stocks are more sensitive to economic conditions during recessions. Johnson (2002) argues that stock price is a convex function of expected growth, meaning that risk increases with growth rates and hence the winner stock returns are supposed to be more sensitive to the changes in expected growth during the expansions and higher momentum premium should be expected. Hence, past winners (past losers) tend to have higher (lower) growth rate changes in the recent past, as well as higher (lower) subsequent expected returns, according to Kim et al. (2014). They find that momentum profits are pro-cyclical and they can be explained by timevarying risk. Similar link between momentum returns and risk is documented in Maio \& Santa-Clara (2011), who argue that momentum anomaly could be explained by time varying betas, reinvestment risk and interest rates.

Using size, value and momentum premium data from Gregory, Tharyan, \& Christidis, (2013) and Markov switching model methodology, this paper seeks to contribute to the literature by providing the first comprehensive study of the effect of a set of relevant macroeconomic variables on those premiums in the UK market over varying economic regimes. The Markov switching framework in this study is closely related to Perez-Quiros \& Timmermann (2000) and Gulen et al. (2008), where the former investigate the systematic difference in variation of size premium while the latter focuses on variations in value premium over the US business cycles. In this study, we comparatively examine the impact of UK macroeconomic variables, such as GDP growth, interest rates, money supply, credit spreads etc. on all three UK equity premiums (small, value and momentum) across high and low volatile market states. We also explore whether cyclical differences in premiums lead to asymmetries in the economic value added (Sharpe ratios) to investors across the two states. To do this, we apply a simple trading rule that allows us to switch between a style/size portfolio and UK one month Treasury bill, depending on the sign of the portfolio's forecasted return. We then assess the differences in Sharpe ratios of the strategy during recessions, expansions and the full sample period relative to a buy-and-hold benchmark. We evaluate whether the trading is feasible at a reasonable level of transaction costs.

We relate Markov switching low volatility regime (regime 1) with market expansion and high volatility regime (regime 2) with recession, using OECD UK Recession Indicator. Our findings reveal that the most pronounced asymmetry across market states is associated with 
the size premium, followed by the value premium, while the least asymmetric is the momentum premium. The size premium changes sign from positive in expansions to negative in recessions. Overall, in our sample, macroeconomic variables have more significant impact on the three premiums in the recessions. We document that credit market conditions variables, namely interest rates, term structure and credit spread have the greatest significant impact on the level of the three premiums, particularly in the downmarket. In addition, GDP growth has strong significant impact on small and value premium in both market states, while money supply growth has significant effect on the two premiums only in economic downturns. Momentum premium is unaffected by unexpected inflation, GDP and money supply growth regardless of the market state, but remains influenced by credit market variables in both states. Our trading rule results confirm the asymmetry of the premiums over economic cycles, particularly the size premium. The Sharpe ratios are lower in recessions then in expansions, which is in line with our Markov switching model results that suggest lower premiums in recessions, and in turn lower returns for investors. Nevertheless, compared to buy and hold strategy, our trading rule fares well, particularly during recessionary periods. Specifically, portfolios of small capitalisation stocks sorted by book-tomarket ratios and momentum generate greater Sharpe ratios than the corresponding buy-andhold strategy in recessions, while in expansions their economic value added is at best equal to that of the buy-and-hold. This simple trading applications shows that our model is able to successfully differentiate between the two market states and can lead to profitable trading in the down-market after transaction costs are taken into account. These findings show that economic indicators can be utilized particularly by UK small cap investors at a very reasonable level of transaction costs, implying that these costs are unlikely source of the limits to arbitrage.

The remainder of the paper is organised as follows: Section 2 outlines methodological framework and describes the data; Section 3 discusses the findings before concluding the paper in Section 4. 


\section{$2 \quad$ Data and Methodology}

\subsection{Style Premiums}

This study uses monthly UK market data from July1982 to June 2014. The UK SMB, HML and UMD premium data is from Gregory, Tharyan, and Christidis (2013) ${ }^{2}$, which is comparable with the Fama-French's and Carhart's US equivalents. After sorting on market capitalization, Gregory, Tharyan, and Christidis (2013) form two size groups of UK stocks, namely ' $\mathrm{S}$ '-small and 'B'-big by using the median market capitalization of the largest 350 companies in the year ' $\mathrm{t}$ ' as the size break point. Similarly, three book-to-market groups, named ' $\mathrm{H}$ '-High, 'M'-medium and ' $\mathrm{L}$ '-Low are formed by using the 30th and 70th percentiles of book-to-market of the largest 350 firms as break points for the book-to-market. Six intersecting portfolios: $\mathrm{SH}$; SM; SL; BH; BM; BL are formed (where "SH" is the small size high book-to-market portfolio, "SL" is the small size low book-to-market portfolio, "BL" is the big size low book-to-market portfolio and so on). SMB and HML factors are then calculated as:

$\mathrm{SMB}=(\mathrm{SL}+\mathrm{SM}+\mathrm{SH}) / 3-(\mathrm{BL}+\mathrm{BM}+\mathrm{BH}) / 3$

And,

$\mathrm{HML}=(\mathrm{SH}+\mathrm{BH}) / 2-(\mathrm{SL}+\mathrm{BL}) / 2$

UMD (momentum) factor is constructed using size and prior (2-12 month) returns ${ }^{3}$. Gregory et al. (2013) create six portfolios, namely SU (small size and high momentum portfolio); SM (small size and medium momentum portfolio); SD (small size and low momentum portfolio); BU (big size and high momentum portfolio); BM (big size and medium momentum portfolio) and BD (big size and low momentum portfolio). The UMD (Up-Minus-Down, i.e. high minus low momentum return) factor is then calculated as:

$\mathrm{UMD}=(\mathrm{SU}+\mathrm{BU}) / 2-(\mathrm{SD}+\mathrm{BD}) / 2$

Note that the components used to form the SMB, HML and UMD factors factor are equally weighted.

\footnotetext{
${ }^{2}$ Downloadable from: http://business-school.exeter.ac.uk/research/areas/centres/xfi/research/famafrench/files/ (Accessed on 20/07/2015)

${ }^{3}$ The prior return at the end of month $t$ is the cumulative return from month $t-12$ to month $t-2$. January is excluded from the calculation to adjust for the seasonal anomalies.
} 


\subsection{Macroeconomic Factors}

A selection of the UK macroeconomic factors in this study, namely GDP growth, Inflation, Interest rate, Term spread, Credit spread and Money supply, are commonly used in the literature of the predictability of stock returns. Table 1 lays out the variables used in this paper as potential determinants of the changes is style premiums across economic regimes; their expected relationship with the SMB, HML and UMD premium respectively, the literature that identifies those relationships, the source of data and definition for each variable.

\section{- Table 1 around here-}

GDP indicates real economic growth and a positive relationship between GDP growth and return premium (size, value and momentum) is identified by many (e.g. Chelley-Steeley \& Siganos, 2004; Kelly, 2003; Liew \& Vassalou, 2000; Zhang et al., 2009).

The relationship between unexpected inflation and size premium is assumed to be negative, because small firms are affected more in the environment of unexpected inflation (Zhang et al., 2009); whereas, the relationship with value premium is expected to be positive. This is because value firms pay high dividends relative to growth firms, they perform better in higher inflationary periods (Zhang et al., 2009). According to Fisher's theory if the stocks are hedged against inflation one would expect a positive relationship between inflation and stock returns. Hence the intuitive relationship between momentum premium and inflation is positive. We follow Fama and Gibbons (1984) and Zhang et al. (2009) to calculate the unexpected inflation as per Table 1 .

Further, the increase in the short term interest rates affects badly value firms and small cap firms due to their high leverage, uncertainty of cash flows and low durations in general. Moreover, rising interest rate reflects the worsening of credit market conditions Perez-Quiros and Timmermann (2000) and thus interest rates are likely to be negatively correlated with stock returns Gulen et al. (2008). In this study, we use the UK three month Treasury bill as a proxy for the risk free interest rate.

The term spread can be viewed as an economic activity indicator and it is a proxy for risk premium. In economic upturn the term spread decreases because short term interest rates increase more than long term interest rates. Whereas, during economic downturn short term 
interest rates decrease and the spread between long and short term interest rates increases. Term spread may therefore affect expected stock return because it affect the company earnings Lucas et al. (2002). The intuitive relationship between term spread and style premium is positive. We define term spread as the difference between the yield on a 10 year UK government bond and the UK three month Treasury bill.

Credit spread or default spread has long been used in the literature as a proxy of credit market conditions, see for example Chen et al. (1986), Gertler, Hubbard, \& Kashyap (1990); Kashyap, Lamont, \& Stein (1994); Keim \& Stambaugh (1986), Perez-Quiros and Timmermann (2000), Griffin, Ji and Martin (2003), Gulenet al. (2008), etc. We define credit spread as the difference in yields between high yield corporate bond ${ }^{4}$ and 10-year UK government bond. The intuitive relationship between credit spread with value and momentum premium is positive. However, since small firms tend to be newcomers, poorly collateralized and don't have full access to the external financial markets, they have relatively stronger adverse effects than large firms to the worsening credit market conditions. On average, an increase (decrease) in the credit spread is expected to be associated with lower (higher) returns of SMB. Moreover, asymmetries are expected for the credit spread variables since small firms are likely to be more exposed to credit market conditions during recession (PerezQuiros and Timmermann, 2000).

Finally, the change in money supply variable proxies the liquidity changes and monetary policy shocks Gulen et al. (2008). It also measures the monetary policy shocks that might affect aggregate economic conditions. Intuitively, changes in money supply affect the economic conditions and investment premium as they indicate the credit market conditions. One could expect a higher return when there's an increase in money supply. Smallest firms are found to be particularly strongly positively affected by money supply growth during recessions in the study of Perez-Quiros \& Timmermann (2000).

\subsection{Relationship Between the Premiums and Macroeconomic Factors}

\footnotetext{
${ }^{4}$ Note that the high yield corporate bond data is not available for the UK market a period longer than 11 years. To cover longer span of varying economic regimes, we resort to Moody's US BAA corporate bond index as a proxy for the UK data. The correlation coefficient Thomson Reuter UK Corporate Benchmark BBB (available since April 2002) and Moody's US BAA is 0.871085 over the 11 year period.
} 
To get an indication of the relationship between a set of macroeconomic variables selected and each of the three premiums for the overall sample period, we run three separate multifactor OLS regressions of the following form:

$r_{i t}=\alpha_{1}+\beta_{i 1} G D P G_{t-1}+\beta_{i 2} I N F_{t-1}+\beta_{i 3,} I R_{t-1}+\beta_{i 4} T E R M_{t-1}+$

$\beta_{i 5} C_{R E D I T}+\beta_{i 6} \Delta M_{t-2}+\varepsilon_{i t} \quad ; i=$

$(S M B, H M L, U M D) ;) ; \varepsilon_{i t} \sim N\left(0, \sigma_{i t}^{2}\right)$

While OLS can serve as an indicator of the relationship between factor premiums and macroeconomic variables, if asymmetries in the data do exist, the OLS is not the appropriate model to use, as it does not account for different economic states. To test for any presence of asymmetry in relationships given in equation (1) in high and low volatility regimes, we adopt the Markov Switching Model methodology.

\subsection{Econometric Framework for Markov Switching Model}

We assume that investors' investment decisions vary across different economic regimes and further, we assume the relationship between style returns (size, value and momentum) and macroeconomic variables also varies. To characterize economic regimes in style investment return, Perez-Quiros and Timmermann (2000), Guidolin and Timmermann (2008), Gulen, Xing and Zhang (2008), Chung, Hung and Yeh (2012) adopt a two-stage Markov switching model approach. The Markov Switching model was pioneered by Hamilton (1989) and over the years gained popularity for studying the asymmetries across business cycle regimes Layton and Smith (2007). The model allows shifts from one regime to another and gives probabilities of such transitions. It also takes into account certain types of non-stationarity inherent in economic or financial time series data that cannot be captured by classical linear models. These economic and financial time series might obey to different economic regimes characterized by economic events such as financial crisis (Jeanne and Masson, 2000) or abrupt economic policy changes (Hamilton, 1988), which is relevant for our study. From the econometrics point of view, the main challenge of estimating Markov Switching model is the un-observability of the prevailing regime Ammann and Verhofen (2006).

The Markov Switching framework of this study closely related to Perez-Quiros \& Timmermann (2000) and Gulen et al. (2008). We model size, value and momentum premium as follows: 
$r_{i t}=\alpha_{i}+\beta_{i 1, s_{t}} G D P G_{t-1}+\beta_{i 2, s_{t}} I N F_{t-1}+\beta_{i 3, s_{t}} I R_{t-1}+\beta_{i 4, s_{t}} T E R M_{t-1}+$

$\beta_{i 5, s_{t}} C R E D I T_{t-1}+\beta_{i 6, s_{t}} \Delta M_{t-2}+\varepsilon_{i t} \quad ; i=(S M B, H M L, U M D)$

Here, $r_{i t}=\left(S M B_{t}, H M L_{t}, U M D_{t}\right)^{\prime}$ is the $(3 \times 1)$ vector of three different style portfolio returns, and $\varepsilon_{i t}$ is normally distributed error term with mean 'zero' and variance $\sigma_{i s_{t}}^{2}$, with $S_{t}=\{1,2\}$, namely regime 1 and regime $2 . G D P G$ is the GDP growth rate, INF is the unexpected inflation; $I R$ is a three month Treasury bill, used as a proxy of short term interest rate; TERM is the difference between the ten year Government bond and three month Treasury bill, representing a term spread; CREDIT is the credit spread defined as the difference in yield between high yield bond and ten year Government bond; $\Delta M$ is the log change in money supply, used as a proxy for liquidity changes in the economy.

Following the study of Perez-Quiros and Timmermann (2000), Gulen, Xing and Zhang (2008) and Kim et al. (2014), this study uses the lag of one-month for GDP growth, Inflation, Interest Rates, Term Spread and Credit Spread; whereas, money supply growth is lagged by two months to allow the publication delay of this variable. The model is estimated by the two-state Markov switching model with time varying transition probabilities, which is feasible estimation method with non-normal data ${ }^{5}$.

The transition probabilities for the above model are specified as:

$$
\begin{aligned}
& P_{11}=P\left(s_{t}=1 \mid s_{t-1}=1, z_{t-1}\right)=\Phi\left(\pi_{0}+\pi_{1} C L I_{t-2}\right) \\
& P_{12}=1-P_{11}=P\left(s_{t}=1 \mid s_{t-1}=2, z_{t-1}\right) \\
& P_{22}=P\left(s_{t}=2 \mid s_{t-1}=2, z_{t-1}\right)=\Phi\left(\pi_{0}+\pi_{2} C L I_{t-2}\right) \\
& P_{21}=1-P_{22}=P\left(s_{t}=2 \mid s_{t-1}=1, z_{t-1}\right)
\end{aligned}
$$

Here, $s_{t}$ is the indicator of regimes for each of the style portfolio and $\Phi$ is the cumulative density function of standard normal variable. CLI is the OECD's Composite Leading Indicator. Prior literature shows that the transition probabilities between regimes are time varying and depend on information variables such as economic leading indicator (see for e.g. Filardo, 1994, Perez-Quiros \& Timmermann, 2000, Gulen et al., 2008, Chung et al., 2012). Layton (1998) argues that, such transition probabilities adjusted by information variables or leading indicators provide very close correspondence to the business cycle chronology. To

${ }^{5}$ See, Hamilton (1988), Hamilton (1994), Kim \& Nelson (1999) and Jeanne \& Masson (2000). 
ensure transition probabilities are accurately defined prior studies used logarithmic lag difference of Composite Leading Indicator. The Composite Leading Indicator is designed to anticipate the turning point of economic cycles relative to trend and continue to signal diverging growth patterns across the corresponding economy. The indicator suffers from back-filling bias, as it is published when $60 \%$ of its data is available and revised as more data is included. There is a 2 month publication lag for input data for this indicator so that the data for month ' $\mathrm{t}$ ' is available in month ' $\mathrm{t}+2{ }^{\prime}$. To avoid back-filling bias, we apply CLI indicator with lag 2 in this study (as in Perez-Quiros \& Timmermann, 2000 and Gulen et al., 2008).

\subsection{Identification of the States}

Figures1, 2 and 3 provide an indication of the relation between the Markov switching states and economic regimes. All three figures display the regime probabilities of being in low volatile regime (regime 1) and high volatile regime (regime 2 ) for size, value and momentum premium respectively at time $\mathrm{t}$ with the conditional information at time $\mathrm{t}-1$. Here, $\mathrm{P}(\mathrm{S}(\mathrm{t})=1)$ and $\mathrm{P}(\mathrm{S}(\mathrm{t})=2)$ are the probability of being in regime 1 and regime 2 respectively. The shaded area is the OECD based Recession Indicators for the United Kingdom taken from Federal Reserve Bank of St. Louis. It can be observed that the predicted probabilities of being in the high volatile (low output) regime coincide with the recessionary period. Figure 1 and 2 illustrate that the smoothed regime probabilities display clear time variation of small cap and value premium across the states of the economy and the probabilities of being in regime 2 are high during the recessions. Figure 3 also displays the time variation of momentum premium across the economic states but the probabilities of being in regime 2 when there is economic downturn are notable however not as high as those for small and value premium. The least time variant across economic states is the value premium (Figure 2). Most variation in value premium is observed at the start of 2001/02, around the dot-com bubble burst. During that time, we note a very high probability of value premium being in regime 2 (downturn). These results overall give support to the fact that the regime 1 can be classified as the state of economic upturn and regime 2 as the state of economic downturn.

Moreover, we find that that the regime 2 is associated with the high conditional volatility, measured by conditional standard deviation reported in Table 3 for the size, value and momentum premium. These findings are in alignment with those of Schwert (1990),

\footnotetext{
${ }^{6}$ http://www.oecd.org/std/compositeleadingindicatorsclifrequentlyaskedquestionsfaqs.htm
} 
Hamilton and Lin (1996), Gulen et al. (2008), Perez-Quiros \& Timmermann (2000) and Kim et al. (2014). Given this, it can be inferred that the regime 1 corresponds to economic upturn and regime 2 to the economic downturn, which are characterised by low and high volatilities respectively.

- Figure 1 around here -

- Figure 2 around here -

- Figure 3 around here -

\section{$3 \quad$ Empirical findings}

\subsection{Descriptive Statistics}

Table 2 presents the descriptive statistics (mean, standard deviation, skewness and kurtosis) of the UK size, value and momentum premium in the overall sample period (Panel A) and in economic downturns and upturns ${ }^{7}$ separately (Panel B). The monthly mean returns of size, value and momentum premium in the overall sample period reported in Panel A are $0.12 \%$, $0.34 \%$ and $0.95 \%$ with the standard deviation of $3.1 \%, 3.2 \%$ and $4.4 \%$ respectively.

- Table 2 around here -

Panel B shows the domination of momentum premium with the mean return (and standard deviation) being highest in both regimes. Panel B documents that while the fall in value and momentum premiums in recessions is very marginal, the size premium exhibits a notable change. It shifts from positive $(0.34 \%)$ in expansions to negative $(-0.07 \%)$ in recessions, which indicates poor performance of small firms during the tight credit market conditions. Decrease in size premium in the downmarket state is also documented by Kim \& Burnie (2002). Further, in the overall sample period (Panel A), all but the SMB premium are significantly negatively skewed with kurtosis higher than 3 in all the cases, implying nonnormal distribution. Similar characteristics are also observed during the two economic cycles.

\footnotetext{
${ }^{7}$ As defined by OECD's Composite Leading Indicator (CLI) described in section 2.4 of the paper
} 


\subsection{Multiple OLS Results}

Table 3 provides a summary of the relationship between each of the return premiums and macroeconomic variables used in this paper. It is apparent that increases in GDP, inflation, credit spread and money supply growth are causing significant increase in the size premium. Similarly, short term interest rates and credit spread have a significant positive impact on value premium. However, the OLS results show that no macroeconomic variable impacts momentum premium over our sample period. The intuition behind some of these relationships will be explained in the next section.

\section{- Table 3 around here -}

These OLS results are only indicative of the relationship between the premiums and macroeconomic variables but they do not tell us anything about the change in the size of the premium in recessions and expansion, or about variables that may be more (or less) influential across the two regimes. The low level of $\mathrm{R}^{2}$ shows that OLS as a method of estimation has limitations when asymmetries in the data are present and when the assumptions of normal distribution are violated (note that descriptive statistics in Table 2 illustrates that the data is not normal).

\subsection{Markov Switching Model Results}

Table 4 reports the parameter estimation of the equation (1) by the Markov switching model. The constant term $\left(\alpha_{1}\right)$ in regime 2 is lower than those of regime 1 universally for all the style premiums. This indicates lower expected value of the SMB, HML and UMD after adjusting for the macroeconomic risk factors in the regime 2 then in regime 1. Except for the size in regime 1 , all of the constant terms are statistically significant across the regimes. The highest constant is the one associated with the momentum premium in both regimes. The most notable change is associated with size premium both in terms of its magnitude (a change of $0.26 \%$ ) and its sign, which changes from positive in expansion to negative in recession. This conclusion is consistent with the one associated with mean values of the three premiums in expansions and recessions reported in Table 2. The constants in Table 4 therefore imply that the investors in the UK market would benefit more from investing in large capitalization firms with good growth opportunities in the recessions, but that the premium on holding winners will be lower than in expansions. This is in line with Arshanapalli et al. (2004) and 
Fama and French (1993) who argue that firmswith small capitalization, high book-to-market ratios (value firms) and past winners are more likely to be distressed and vulnerable during bad economic conditions and investors will be better off avoiding them.

- Table 4 around here -

What becomes apparent from Table 4 is that macroeconomic variables popularly used in the literature as determinants of size, style or momentum premiums are of greater significance in the recessions than in expansions. For instance, looking at the SMB or HML premium in recessions, all explanatory variables are significant at $1 \%$ level (the only exception being the impact of inflation on value premium); while for UMD premium the variables describing credit market conditions (interest rates, term structure and credit spread) fare as the most significant ones. In expansions, both the number of significant variables and their level of significance is lower for each of the three premiums. Out of six explanatory variables commonly considered in the style premiums literature, the significant positive drivers of the small cap premium in the up market are GDP growth (significant at 10\%) and inflation (significant at 5\%) while increase in the term structure decreases small cap premium (significant at 10\%). GDP growth, interest rates, term structure and credit spread all have positive and significant impact on value premium in expansions; while at the same time momentum premium is highly negatively influenced by the increase in interest rates (significant at 5\%) and the increase in credit spread (significant at 1\%), but remains unaffected by the remaining variables.

Let us now examine the further impact of each of the macroeconomic variables on the three premiums and provide some rationale behind the documented relationships. Table 4 reveals the significant positive relationship between the GDP growth and small and value premium in regime 1. When the economy is doing well a further increase in the GDP growth signals increase in small cap and value premium as the literature (see Table 1) suggests. While this relationship holds for small cap premium in regime 2 as well, we find that the growth in GDP decreases premium on UK value stocks in recessions. This can be explained by the fact that value companies are concentrated in industries that are cyclical in nature (utilities, banking, etc.) and heavily affected by recessions, so even if the GDP grows in the recession it does not improve returns of value companies until the end of the recession cycle. We do not observe any significant relationship between momentum premium and GDP growth in either economic state. 
The inflation coefficient is only significant for size premium, taking positive values during both regimes. Such positive and significant relationship implies that small capitalization stocks benefit from inflation, as the small firms find it relatively easier to pass along price increases in inflationary times, as argued by Anderson (1997). Since value firms pay higher dividends than growth firms, they perform better when inflation increases, as suggested by Zhang et al. (2009). While we find the relationship between value premium and unexpected inflation to be positive, it is insignificant in both economic states; the same is observed for the momentum-unexpected inflation relation.

According to the credit channel theory of monetary policy (Bernanke and Gertler, 1995) monetary tightening increases the financial costs and restricts the access to external financing. This monetary tightening has stronger effect to the firms in poorer financial positions. Our findings are in line with this theory, suggesting that since small firms tend to be low duration firms with high leverage and cash flow problem, higher interest rates will restrict their access to external financing, which is particularly relevant during economic downturns. The small cap premium - interest rates relationship therefore exhibits asymmetry and turns from negative (albeit insignificant) in expansions to positive (significant at 1\%) in recessions. Similarly, we find support for a positive relationship between value premium and interest rates in both market regimes, significant at $1 \%$ level. This is consistent with Black and McMillan (2005), indicating that value investors seek higher returns to compensate increased returns on competing assets, such as fixed income instruments. Finally, the increase in interest rates by $1 \%$ decreases momentum premium by $23.83 \%$ in regime 1 and $1.83 \%$ in regime 2 , both values being significant at $5 \%$ level. Hence, past winners are more adversely affected by the increases in short term interest rates than past losers in both economic states, however notably more so in expansions.

The relationship between the term structure and size exhibits asymmetries over economic regimes. The relationship turns from negative in regime 1 to positive in regime 2. Aretz, Bartram \& Pope (2010)argue that shocks to term structure will have greater effect on larger firms than on the smaller ones and hence a positive relationship is expected between term spread and size premium. Our results confirm this view in economic downturn. In the upturn, the negative relationship between term spread and size premium may be explained by the fact that small firms often do not have as much collateral as large firms and have a lesser ability to raise external funds, hence restricting the potential growth. 
Further, similar to Gregory, Harris, \& Michou (2003), we find that during expansions, an increase in term structure has greater positive effect on value premium. The effect turns to negative in recessions, implying that increase in term spread is decreasing the value premium. Note that in expansions, even if the term structure increases, the yield curve is still relatively flat. However, in economic downturns, when the yield curve steepens, it affects more adversely growth stocks than value stocks due to their non-payment of dividends and longer durations. Hence, it is expected that investors ask for greater premium on growth stocks in recessions, which is in line with our findings from Table 4. Finally, we document the negative relationship between the term spread and momentum premium in recession indicating that the past losers benefit from the steepening of yield curve. One plausible explanation of this relationship is that winner firms tend to have higher market betas, moving more in line with the market than loser stocks. Hence, in a situation when short-term interest rates fall below long term interest rates winner stocks are adversely affected because of the cyclical behaviour of winner stocks.

An increase in credit spread is commonly interpreted as a sign of worsening credit market conditions. One would expect positive relationship between credit spread and style premiums. We find evidence that corroborates this in both regimes and document a positive coefficient of credit spread with size and value premiums during both economic states. This finding coincide with the findings of Fama and French (1988) and Fama and French (1989). This might indicate that small and value firms require greater compensation of taking higher risk when the credit spread is higher. Higher magnitudes of credit spread during recessions for size and value premiums indicate that firms exposed to tightening credit market conditions respond more to increased credit risk. Nevertheless, contrary to Kim et al (2014), we find that the credit spread coefficient is negative for momentum premium in expansions, indicating that past losers enjoy higher return than past winners during economic upturn.

Money supply growth shows asymmetries with value premium. The relationship turns from insignificant in market upturns to negative during downturns. One possible explanation can be that value investors interpret increase in the growth of money supply in recessions as a positive indicator of expansionary monetary policy that will stimulate growth in the economy and make the environment more suitable for value firms, thus causing value premium to drop. At the same time, growth firms take the advantage of higher money supply despite of the higher risk in economic downturn. A positive relationship of growth in money supply and 
size premium is found during downmarket, indicating that when there is expansion in monetary growth in recessions, the small cap stocks are at their highest level in terms of risk premiums, as noted by Perez-Quiros \& Timmermann (2000). This can be explained by the fact that even though growth in money supply signals acceleration of economic growth, the lack of small firm's access to credit markets may lead to prolonged effect of the recession on those firms and in turn requirement of the higher risk premium.

Overall, our results clearly show that the cyclical asymmetry in size, value and momentum premium and their determinants is present in the UK market. The greatest cyclicality is documented with the size premium, which changes sign from being positive in expansion to negative in recession and exhibits the greatest magnitude change. Momentum premium is comparatively the least cyclical one in the UK. Overall, we document more significant impact of macro factors on all the three premiums in the recessions. Macroeconomic variables that proxy credit market conditions (interest rates, term spread and credit spread) are found to have more profound effect on size, value and momentum premium, particularly in the high volatile market state (downmarket). In addition, strong impact of GDP growth in both states and money supply growth in recessions is found for both small and value premium. Momentum premium is not affected by unexpected inflation, growth in GDP and money supply regardless of the market state; putting credit market conditions variables as the lead contributors to the changes in this premium in the UK in up- and down-markets.

\subsection{Model Diagnostics}

While Table 4 shows that there are differences in how size, value and momentum premiums respond to changes in macro variables across the two regimes, the differences in intercepts or coefficients are not statistically verified. To test for significance of asymmetries in our sample and significance of our Markov switching model overall, we start by employing a Wald test to assess if the intercepts and coefficients of six conditioning variables (GDP growth, inflation, interest rates, term spread, credit spread and money supply growth) are identical across regimes for the size, value and momentum premiums, applying the following hypothesis:

For size premium: $H_{01}: \beta_{S M B, j,\left(s_{t}=1\right)}=\beta_{S M B, j,\left(s_{t}=2\right)} ; j=1,2,3,4,5,6$

For value premium: $H_{02}: \beta_{H M L, j,\left(s_{t}=1\right)}=\beta_{H M L, j,\left(s_{t}=2\right)} ; j=1,2,3,4,5,6$ 
For momentum premium: $H_{03}: \beta_{U M D, j,\left(s_{t}=1\right)}=\beta_{U M D, j,\left(s_{t}=2\right)} ; j=1,2,3,4,5,6$

Table 5 reports that Wald test values of Chi-Squared distribution with 6 degrees of freedom and the p-values. The significant Chi-Square statistics reject the null hypothesis in favour of regime dependency for all the size, value and momentum premiums. These results identify that the switching model is statistically significant, implying the differential response of style premiums and their determinants to aggregate economic conditions in the economic downturn and economic upturn. Our results fare well with Perez-Quiros \& Timmermann (2000), Gulen et al.(2008) and Kim et al. (2014).

\section{- Table 5 around here -}

To identify the significance of regressors in the model, the likelihood ratio test for redundant variables is performed. Likelihood ratio rest is being performed under the null hypothesis $\beta_{i j}=0, i=S M B, H M L, U M D ; j=1,2,3,4,5,6$; to identify the significance of each regressor, namely industrial production growth, inflation, interest rates, term spread, credit spread and money supply growth. Table 6 reports the likelihood ratio test of redundant variables for the estimated Time Varying Markov Switching model.

\section{- Table 6 around here -}

With the exception of inflation in determining value and momentum premium and money supply growth in determining the momentum premium, the likelihood ratio test is significant for all of the remaining regressors of size, value and momentum premiums. These results corroborate the overall significant impact our chosen macroeconomic variables have on the three premiums.

\subsection{Regimes Robustness Check}

We test the robustness of our model by estimating model parameters using the change in the UK Industrial Production (IP) index with one period lag as an alternative information variable in modelling transitions probabilities instead of CLI lagged by two periods. IP index is often used as a proxy of economic activity. The results in Table 7 indicate that our model is robust to the variable used to define the state of economic cycle. The most asymmetry is present in the SMB intercept, which changes from positive (albeit insignificant) to negative, while HML and UMD change magnitude but not the sign. By and large, the signs of the coefficients remain unchanged compared to Table 4. Credit market conditions variables 
(interest rates, term and credit spread), still have the greatest and most significant overall impact across regimes for all the premiums. They are followed by the change in the money supply, which has a significant impact on the premiums in the recessions.

- Table 7 around here -

\subsection{Economic Value of the Model and Limits to Arbitrage}

In the previous sections, we have identified the presence of asymmetries in the size/style premiums in the UK. It is of interest to practitioners to explore economic significance of these findings by testing the profitability of a trading strategy based on our model's predictions. It is important to note that some of the economic indicators we find significant in the Markov Switching model might me proxies for the limits of arbitrage. This implies that size/style premiums we have identified in recessions and expansions will persist as investors are not able to exploit them due to certain constraints. Barberis and Thaler (2003) argue that the arbitrage opportunities will not be adequately seized if idiosyncratic risk is high, if noise trading momentum risk is present and if transaction costs associated with trading strategies are high. While assessment of the idiosyncratic risk and nose trading risk is beyond the scope of this paper, we will assess the impact of transaction costs to profitability of our strategy as an indicator of presence of limits to arbitrage.

We acknowledge that a pure arbitrage strategy will involve long-short investing, but given that typical investors in the UK market are long-only (mutual funds for instance) and pursuing conservative strategies (pension funds for instance), investing in Fama-French factors that are based on long and short positions will not be possible for them. Having this in mind, we employ long-only asset allocation strategy feasible for the typical UK investors, similar to that given in Perez-Quiros and Timmermann (2000). We start by applying our model to each of the eight size/style portfolio returns available from Gregory, Tharayan, and Christidis (2013) database, namely: small cap-value, small cap-growth, large cap-value, large cap-growth, small cap with-negative momentum, small cap with-positive momentum, large cap with-negative momentum and large cap with-positive momentum. Our data sample is split into 306 in-sample months and 78 out-of-sample (trading) months from July 1982 to June 2014. Using our model and the data July 1982 - December 2007, we forecast the return for January 2008 for each of the eight portfolios. If the forecasted return for a portfolio is 
positive, we invest in that portfolio in January 2008. In the case of negative forecast returns, the funds are invested in the proxy for the risk-free asset - UK One Month Treasury Bill. The procedure is then repeated recursively out-of-sample over 78 trading months, until June 2014. Our investment strategy is therefore a switching strategy based on alternating between the given size/style portfolio and the T-bill, depending on the sign of the forecast. There are 52 recession months and 26 expansion months in our trading period.

We compare each portfolio switching strategy to the corresponding buy-and-hold benchmark. Buy-and-hold is defined as the investment in the relevant size/style sorted portfolio over the entire 78-month trading period. The risk-adjusted profitability of the switching strategy for each portfolio vs. its buy-and-hold benchmark is measured by the Sharpe ratios. To assess the feasibility of our allocation strategy for investors, we calculate the break-even level of transaction costs per switch for each portfolio. Those are maximum costs per trade that will equalise the Sharpe ratio of the switching strategy to that of the buy-and hold benchmark. The higher the break-even transaction costs are, the more feasible our strategy is.

Table 8 reports annualised mean return, standard deviation, Sharpe ratio, the number of switches and break-even transaction costs per switch for each of the eight switching portfolios. Comparative figures (where applicable) are reported for the buy and hold portfolios. Panel A (Panel B) lays out results for four strategies involving small cap (large cap) portfolio groups: with low book-to-market ratio, with high book-to-market ratio, with down momentum and with up momentum. Results are split into full period, expansion and recession sub-periods.

-Table 8 around here -

Given the Sharpe ratios in Panel A, all four small cap switching portfolio categories outperform their buy-and-hold benchmarks in the out-of-sample period January 2008-June 2014. The average Sharpe ratio of switching portfolios in the full sample in Panel A is 0.65, compared to that of 0.55 of the relevant benchmarks. Breakeven transaction costs are well above at least 100 basis points per trade for all but small cap with up momentum switching portfolio (18.55 bps), showing that our small size/style switching strategy is both profitable and feasible. In contrast, Panel B documents that while switching strategies of portfolio of large firms sorted on momentum are not underperforming the buy-and-hold in any instance, their outperformance is not that notable. Large cap portfolio with down momentum generates 
only marginally higher Sharpe ratio (0.16) than their benchmark (0.15) in the full sample and a less negative Sharpe ratio in recessions. Alternating between large cap firms sorted on book to market and the risk free rate does not lead to above-benchmark profitability in any instance. Overall, we show that the forecast from our model has economic value for small cap strategies and is not subject to the limits of arbitrage proxied by transaction costs; while this is less pronounced in the large cap space.

Looking at the differences in profitability across economic regimes, the key findings in Table 8 can be interpreted as absolute (level changes of Sharpe ratios in expansions and recessions) and relative (compared to that of the buy and hold). In absolute terms, excess returns per unit of risk (Sharpe ratios) on all portfolios decrease when we move from expansion to recession state. This is coherent with our Markov switching model results which show a drop in size, value and momentum premiums in recession, indicating lesser opportunities for investors pursuing those strategies. Note that in our out-of-sample trading period, the drop in Sharpe ratios is highly influenced by the strong negative returns during the period of global financial crisis 2007-2010. Tightening of credit market conditions, which we found to have the strongest impact in determining the size of the three premiums, is a likely cause of this drop. Our findings are in line with those of Perez-Quiros and Timmermann (2000).

When compared to buy-and hold, our trading strategies show better overall relative performance in recession as opposed to expansion. This finding is more pronounced among switching strategies with small cap portfolios (Panel A) than large cap portfolios (Panel B). Specifically, the average Sharpe ratio across four small size switching portfolios is by 0.12 higher than that of the buy-and-hold strategies in recessions. In expansions, it is lower by 0.02 on the average. Their outperformance in recession is distinct at a feasible level of breakeven transaction costs per trade, even for smaller investors. This finding is of particular importance to practitioners, as it proves that our model can successfully differentiate between economic states and that economic indicators used for forecasting are unlikely proxies for the limits of arbitrage ${ }^{8}$.

\footnotetext{
${ }^{8}$ Note that the conclusion regarding limits to arbitrage relates to transaction costs only. Presence of higher idiosyncratic risk and noise trading remains to be tested in future research.
} 


\section{Summary and Conclusions}

This paper is the first to shed light on asymmetries in the UK size, value and momentum premium and identifies the main drivers of these premiums in both expansions and recessions. We focus on UK SMB, HML and UMD factors defined by Gregory, Tharyan, and Christidis (2013) in the period January 1982 to June 2014. Employing Markov switching methodology, we find evidence in strong support of asymmetry in the three premiums across the two Markov switching regimes. Our analysis of regimes related to OECD's UK Recession Indicator prompts us to conclude that Markov switching regime 1, associated with lower conditional volatility coincides by and large with economic upturns and vice versa for regime 2 . We find that all three premiums vary across regimes but that most asymmetries are observed in the size premium and the least in the momentum premium. The UK momentum premium result is in contrast to Kim et al. (2014), who document clear asymmetry in the US market. Nevertheless, ours is the only study that provides direct comparison of all three premiums and their relationship with a set of macroeconomic variables.

Following the US literature, we test whether the growth in GDP, inflation, interest rates, term structure, credit spread and money supply growth are valid determinants of those cyclical variations in UK equity return premiums. We corroborate findings from the US markets in that macroeconomic factors are drivers of equity premiums in both economic upturn and downturn, but have more pervasive and more significant influence in the economic downturn. The strongest impact on size, value and momentum premium have variables that proxy credit market conditions, namely interest rates, term structure and credit spread. Our results are similar to those documented for the US size and value premiums, but when it comes the relationship between momentum premium and interest rates, credit spread and money supply, we find the opposite relationships to those documented in Kim et al. (2014) for the US expansionary periods.

To test the significance of our Markov switching model, we apply the Wald test and redundant variable test (Likelihood Ratio Test). Walt test shows that the intercept and slope of the Markov Switching model are regime dependent and hence there is differential response of style premiums in economic upturn and downturn. Given the Likelihood Ratio Test, all macroeconomic variables across the three premiums are being deemed as significant ones, at the minimum $5 \%$ level of significance, with the exception of inflation (which is adequate 
regressor for small cap premium only) and monetary growth (which is weak in explaining momentum).

Finally, we examine the economic implications of our model in forecasting size/style portfolio returns and of the asymmetries in size, value and momentum premiums on those portfolios. Using eight portfolios sorted on distinctive size/style/momentum combinations we find that conservative trading strategy with portfolios featuring small cap characteristics generates better risk-adjusted performance relative to the buy and hold strategy and relative to the comparable large cap portfolios. Further, we find evidence of cyclicality of equity premiums in both absolute and relative terms. In absolute terms, all trading strategies based on eight style/size portfolios exhibit a drop in Sharpe ratios in the recession. In relative terms, all small cap switching strategies and large cap/negative momentum switching display relative outperformance over their buy and hold benchmarks in recessions, but not in expansions. This implies that forecasts based on our model have considerable economic significance for investors, particularly for trading strategy involving small cap stocks. Transaction costs per trade are at the feasible level, making these costs unlikely cause for the limits to arbitrage, at least in small cap portfolio trading space.

These findings are relevant for the UK size, style and momentum investors interested in determining how to maximise their profits across economic cycles by applying adequate market timing or asset allocation strategies to exploit the changes in the three premiums over time. With this in mind, our paper has some limitations and can be extended in several ways. For instance, one limitation of this paper is that the factor portfolios are constructed using the same breakpoints as described in Fama and French (1993). Given that recent literature points at the fact that those breakpoints are arbitrarily chosen (see for instance Cremers, Petajisto and Zitzewitz, 2012), it would be beneficial to consider if the results are robust to the use of alternative breakpoints. Further, Avramov et.al. (2016) document that factor portfolios may exhibit momentum. While exploring momentum in premiums is not the focus of this study, our further research in this area is focusing on measuring the survival time of momentum in Fama-French factor portfolios. Additionally, our study can be extended to include the two newly available factors from Fama and French (2015) five factor model: operating profitability and investment. 


\section{References}

Anderson, R. (1997), A Large versus Small Capitalization Relative Performance Model. In Market Timing Models. Burr Ridge: Irwin Professional Publishing.

Aretz, K., Bartram, S. M., \& Pope, P. F. (2010), Macroeconomic Risks and CharacteristicBased Factor Models. Journal of Banking \& Finance, 34(6), 1383-1399.

Arshanapalli, B. G., D’Ouville, E. L., \& Nelson, W. B. (2004), Are Size, Value, and Momentum Related to Recession Risk? The Journal of Investing, 13(4), 83-87.

Avramov, D, Cheng S, Schreiber, A \& Schemer, K. (2016), Scaling up Market Anomalies, Working Paper SSRN, http://papers.ssrn.com/sol3/papers.cfm?abstract_id=2709178

Barberis, N. \& Thaler, R. (2003). A survey of behavioral finance, in: G. M. Constantinides, M. Harris, and R. M. Stulz (eds.), Handbook of the Economics of Finance, Elsevier, First edition, Chapter 18, 1053-1128.

Bernanke, B. S., \& Gertler, M. (1995), Inside the Black Box: The Credit Channel of Monetary Policy Transmission. Journal of Economic Perspectives, 9, 27-48.

Black, A. J., \& McMillan, D. G. (2005), Value and Growth Stocks and Cyclical Asymmetries. Journal of Asset Management, 6(2), 104-116.

Black, A., \& McMillan, D. (2002), The Long Run Value Premium and Economic Activity. Univ. of Aberdeen Acct. \& Fin. Working Paper No. 02-05, 1-22.

Carhart, M. (1997), On Persistence of Mutual Fund Performance. Journal of Finance, 52, 5782.

Chan, K. C., \& Chen, N. (1991), Structural and Return Characteristics of Small and Large Firms. The Journal of Finance, 46(4), 1467-1484.

Chelley-Steeley, P., \& Siganos, A. (2004), Momentum Profits and Macroeconomic Factors. Applied Economics Letters, 11(7), 433-436.

Chen, N. F., Roll, R., \& Ross, S. A. (1986), Economic Forces and the Stock Market. Journal of Business, 59(3), 383-403.

Chordia, T., \& Shivakumar, L. (2002), Momentum, Business Cycle , and Time-varying. Journal of Finance, 57(2), 985-1019.

Chung, S., Hung, C., \& Yeh, C. (2012), When Does Investor Sentiment Predict Stock Returns? Journal of Empirical Finance, 19(2), 217-240.

Cremers, M., Petajisto, A. \& Zitzewitz, E. (2012), Should Benchmark Indices Have Alpha? Revisiting Performance Evaluation, Critical Finance Review, 2,1-48

Daniel, K., Hirshleifer, D., \& Subrahmanyam, A. (1998), Investor Psychology and Security Market Under- and Overreaction. Journal of Finance, 53(6), 1839-1885. 
DeBondt, W., \& Thaler, R. (1985), Does the Stock Market Overreact? The Journal of Finance, 40(3), 793-805.

Fama, E. F., \& French, K. R. (1988), Dividend Yields and Expected Stock Returns. Journal of Financial Economics, 22(1), 3-25.

Fama, E. F., \& French, K. R. (1989), Business Conditions and Expected Returns on Stocks and Bonds. Journal of Financial Economics, 25(1), 23-49.

Fama, E., \& French, K. (1993), Common Risk Factors in the Returns on Stocks and Bonds. Journal of Financial Economics, 33(1), 3-56.

Fama, E. F., \& French, K. R. (2015), A Five-Factor Asset Pricing Model, Journal of Financial Economics, 116, 1-22.

Fama, E., \& Gibbons, M. (1984), A Comparison of Inflation Forecasts. Journal of Monetary Economics, 13, 327-348.

Filardo, A. (1994), Business-Cycle Phases and Their Transitional Dynamics. Journal of Business \& Economic Statistics, 12(3), 299-308.

Gala, V. D. (2005), Investment and Returns. Working Paper, University of Chicago.

Gertler, M., Hubbard, R. G., \& Kashyap, A. (1990), Interest Rate Spreads, Credit Constraints, and Investment Fluctuations: an Empirical Investigation. Financial Markets and Financial Crises, 11-32.

Gregory, A., Harris, R., \& Michou, M. (2003), Contrarian Investment and Macroeconomic Risk. Journal of Business Finance and Accounting, 30(1 \& 2), 213-255.

Gregory, A., Tharyan, R., \& Christidis, A. (2013), Constructing and Testing Alternative Versions of the Fama-French and Carhart Models in the UK. Journal of Business Finance \& Accounting, 40(1\&2), 172-214.

Griffin, J., Ji, X., \& Martin, J. (2003), Momentum Investing and Business Cycle Risk: Evidence from Pole to Pole. The Journal of Finance, 58(6), 2515-2547.

Guidolin, M., \& Timmermann, A. (2008), Size and Value Anomalies under Regime Shifts. Journal of Financial Econometrics, 6(1), 1-48.

Gulen, H., Xing, Y., \& Zhang, L. (2008), Value versus Growth : Time-Varying Expected Stock Returns. Financial Management, 40(2), 381-407.

Hahn, J., \& Lee, H. (2006), Yield Spreads as Alternative Risk Factors for Size and Book-toMarket. Journal of Financial and Quantitative Analysis, 41(2), 245-269.

Hamilton, J. (1989), A New Approach to the Economic Analysis of Nonstationary Time Series and the Business Cycle. Econometrica, 57(2), 357-384. 
Hamilton, J. D. (1988), Rational-Expectations Econometric Analysis of Changes in Regime: an Investigation of the Term Structure of Interest Rates. Journal of Economic Dynamics and Control, 12, 385-423.

Hamilton, J. D. (1994), Time Series Analysis. Princeton: Princeton University Press.

Hamilton, J., \& Lin, G. (1996), Stock Market Volatility and the Business Cycle. Journal of Applied Econometrics, 11, 573-593.

Jeanne, O., \& Masson, P. (2000), Currency Crises, Sunspots, and Markov-Switching Regimes. Journal of International Economics, 50, 327-350.

Johnson, T. C. (2002), Rational Momentum Effects. Journal of Finance, 57(2), 585-608.

Kashyap, A. K., Lamont, O. A., \& Stein, J. C. (1994), Credit Conditions and the Cyclical Behavior of Inventories. The Quarterly Journal of Economics, 109(3), 565-592.

Keim, D. B., \& Stambaugh, R. F. (1986), Predicting Returns in the Stock and Bond Markets. Journal of Financial Economics, 17(2), 357-390.

Kelly, P. (2003), Real and Inflationary Macroeconomic Risk in the Fama and French Size and Book-to-Market Portfolio. EFMA 2003 Helsinki Meetings, (October).

Kim, C., \& Nelson, C. R. (1999), State-Space Models with Regime Switching. Cambridge, Massachusetts: MIT Press.

Kim, D. et al. (2014), Time-Varying Expected Momentum Profits. Journal of Banking \& Finance, Vol.49, pp.191-215.

Kim, M., \& Burnie, D. (2002), The Firm Size Effect and the Economic Cycle. Journal of Financial Research, 40(1), 111-124.

Layton, A. P. (1998), A Further Test of the Influence of Leading Indicators on the Probability of US Business Cycle Phase Shifts. International Journal of Forecasting, 14(1), 63-70.

Layton, A. P., \& Smith, D. R. (2007), Business cycle dynamics with duration dependence and leading indicators. Journal of Macroeconomics, 29(4), 855-875.

Liew, J., \& Vassalou, M. (2000), Can Book-to-Market, Size and Momentum be Risk Factors that Predict Economic Growth? Journal of Financial Economics, 57, 221-245.

Liu, L. X., \& Zhang, L. (2008), Momentum Profits, Factor Pricing, and Macroeconomic Risk. Review of Financial Studies, 21(6), 2417-2448.

Livdan, D., Sapriza, H., \& Zhang, L. (2009), Financially Constrained Stock Returns. Journal of Finance, 64(4), 1827-1862.

Lucas, A., van Dijk, R., \& Kloek, T. (2002), Stock Selection, Style rotation, and Risk. Journal of Empirical Finance, 9(1), 1-34. 
Maio, P., \& Santa-Clara, P. (2011), Value, Momentum, and Short-Term Interest Rates. Working Paper, Nova School of Business and Economics.

Mouselli, S., Michou, M., \& Stark, A. (2008), On the Information Content of the Fama and French Factors in the UK. Manchester Business School, Working Paper, No. 559. Availabe at: http://www.econstor.eu/handle/10419/50698.

OECD. (2014), Composite Leading Indicators (CLIs). Leading Indicators and Tendency Surveys. Retrieved from http://www.oecd.org/std/leading-indicators/

Perez-Quiros, G., \& Timmermann, A. (2000), Firm Size and Cyclical Variations in Stock Returns. The Journal of Finance, 55(3), 1229-1262.

Petkova, R. (2006), Do Fama-French Factors Proxy for Innovations in Predictive Variables? Journal of Finance, 61(2), 581-612.

Schwert, G. W. (1990), Stock Retuns and Real Activity: A Century of Evidence. Journal of Finance, 45, 1237-1257.

Steiner, M. (2009), Predicting Premiums for the Market, Size, Value, and Momentum factors. Financial Markets and Portfolio Management, 23(2), 137-155.

Vassalou, M. (2003), News Related to Future GDP Growth as a Risk Factor in Equity Returns. Journal of Financial Economics, 68(1), 47-73.

Zhang, Q. J., et al. (2009), The Link Between Macroeconomic Factors and Style Returns. Journal of Asset Management, 10, 338-355. 
Figure 1: Time Varying Probability of Being in High and Low Volatile Regimes for Size Premium

This figure displays the regime probabilities of being in low volatile regime (regime 1) and high volatile regime (regime 2) for Size premium at time $t$ with the conditional information at time $t$ 1.Here, $\mathrm{P}(\mathrm{S}(\mathrm{t})=1)$ and $\mathrm{P}(\mathrm{S}(\mathrm{t})=2)$ are the probability of being in regime 1 and regime 2 respectively. The shaded area is the OECD based Recession Indicators for the United Kingdom.

Smoothed Regime Probabilities of SMB

Figure 2: Time Series Probability of Being in High and Low Volatile Regimes for Value Premium

This figure displays the regime probabilities of being in low volatile regime (regime 1) and high volatile regime (regime 2 ) for Value premium at time $t$ with the conditional information at time $t$ -

1.Here, $\mathrm{P}(\mathrm{S}(\mathrm{t})=1)$ and $\mathrm{P}(\mathrm{S}(\mathrm{t})=2)$ are the probability of being in regime 1 and regime 2 respectively. The shaded area is the OECD based Recession Indicators for the United Kingdom.

\section{Smoothed Regime Probabilities of HML}
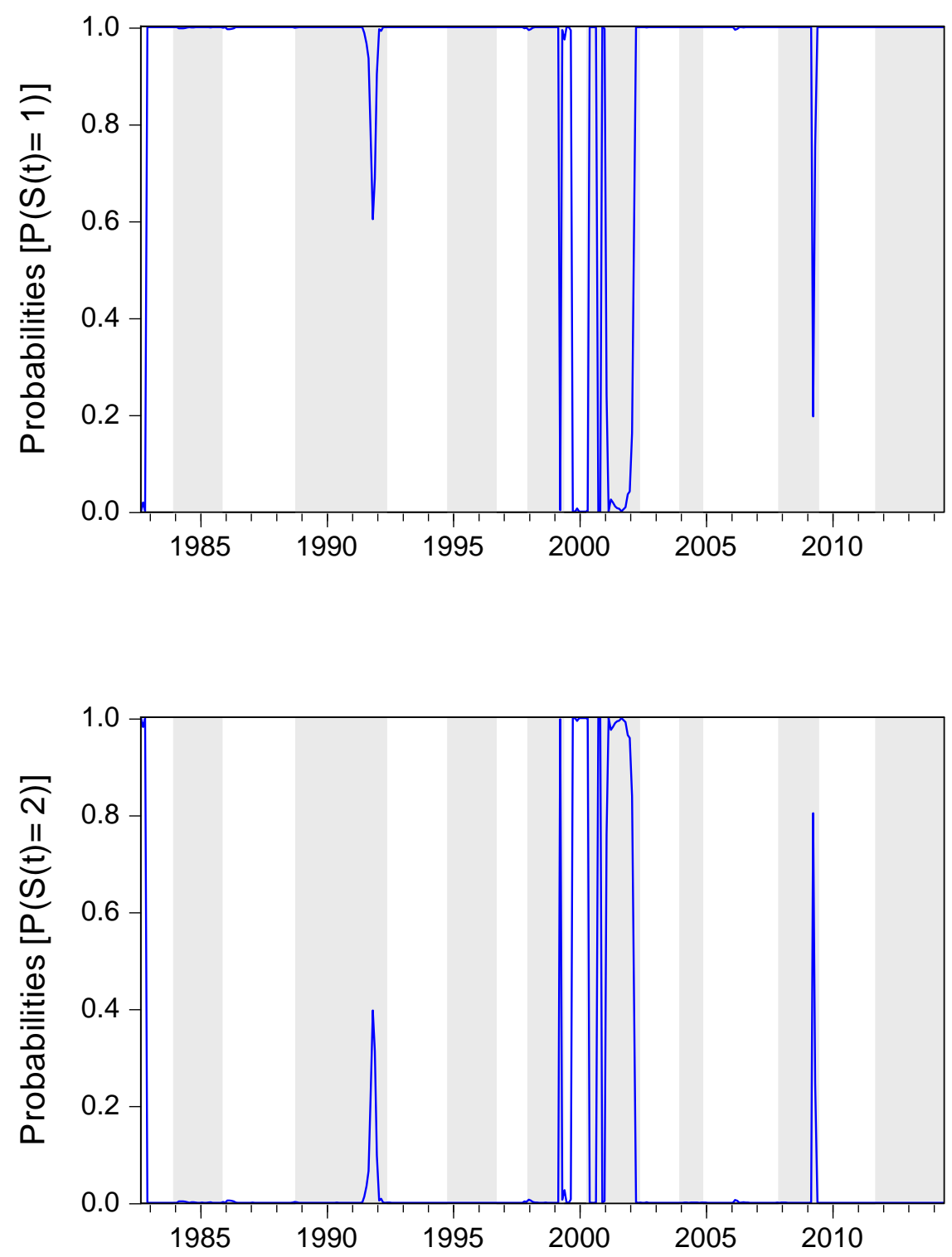
Figure 3: Time Series Probability of being in High and Low Volatile Regimes for Momentum Premium

This figure displays the regime probabilities of being in low volatile regime (regime 1) and high volatile regime (regime 2) for Momentum premium at time $t$ with the conditional information at time $t$-1.Here, $\mathrm{P}(\mathrm{S}(\mathrm{t})=1)$ and $\mathrm{P}(\mathrm{S}(\mathrm{t})=2)$ are the probability of being in regime 1 and regime 2 respectively. The shaded area is the OECD based Recession Indicators for the United Kingdom.

\section{Smoothed Regime Probabilities of UMD}
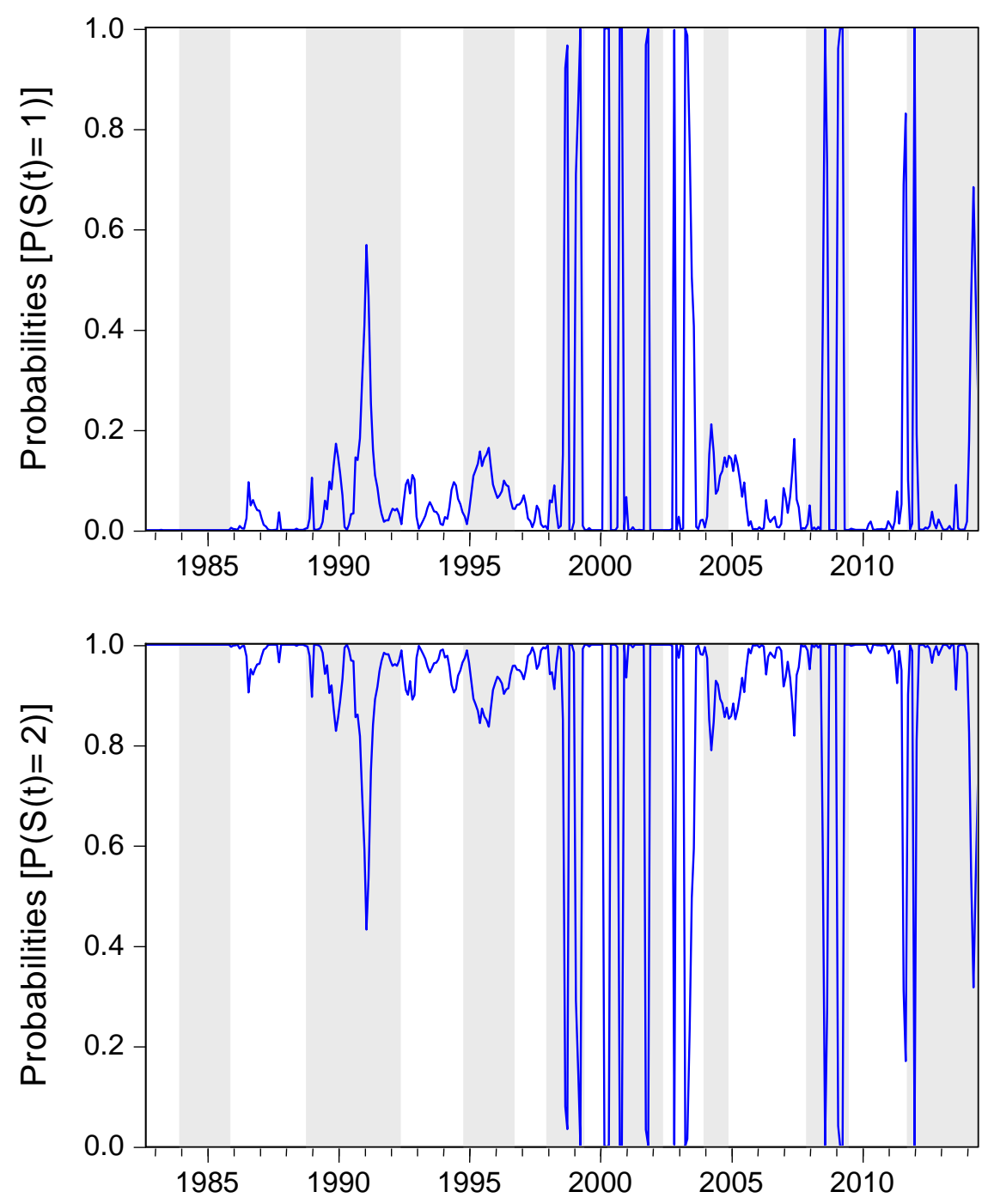


\section{Table 1: Macroeconomic variables}

The table grids all macroeconomic variables used in this study; their expected relationship to SMB, HML and UMD; academic studiesthat report the relationship; how the variable is transformed for the purpose of this study and the source of data

\begin{tabular}{|c|c|c|c|c|c|c|}
\hline Variable name & $\begin{array}{l}\text { Relationship } \\
\text { with SMB }\end{array}$ & $\begin{array}{l}\text { Relationship } \\
\text { with HML }\end{array}$ & $\begin{array}{l}\text { Relationship } \\
\text { with UMD }\end{array}$ & Study which reports the relationship & Variable used in our study defined as: & Data source \\
\hline GDP growth & Positive & Positive & Positive & $\begin{array}{l}\text { Chelley-Steeley \& Siganos (2004), Kelly (2003), Aretz, Bartram, \& } \\
\text { Pope (2010), Liew \& Vassalou (2000), Zhang et al. (2009), etc. }\end{array}$ & GDPgrowth $=\ln \left(\mathrm{GDP}_{\mathrm{t}}\right)-\ln \left(\mathrm{GDP}_{\mathrm{t}-1}\right)$ & $\begin{array}{l}\text { OECD } \\
(2013, b)\end{array}$ \\
\hline $\begin{array}{l}\text { Unexpected } \\
\text { Inflation (I) }\end{array}$ & Negative & Positive & Negative & Kelly (2003), Kim et al. (2014), Zhang et al. (2009) & $\begin{array}{l}\text { Unexpected } \mathrm{I}_{\mathrm{t}}={\text { Realized } \mathrm{I}_{\mathrm{t}}-\text { Expected } \mathrm{I}_{\mathrm{t}}} \\
\text { Realized } \mathrm{I}_{\mathrm{t}}=\ln \left(\mathrm{CPI}_{\mathrm{t}}\right)-\ln \left(\mathrm{CPI}_{\mathrm{t}-1}\right) \\
\text { Expected } \mathrm{I}_{\mathrm{t}}=\text { Tbill }-\sum_{\mathrm{j}=1}^{12} \text { Tbill }_{\mathrm{t}-\mathrm{j}} \\
\text { Where CPI is consumer price index, taking } 2005 \text { as } \\
\text { base year }\end{array}$ & Datastream \\
\hline Interest rate & Negative & Negative & Negative & $\begin{array}{l}\text { Gulen et al. (2008), Kim et al. (2014), Maio \& Santa-Clara, (2011), } \\
\text { Zhang et al. (2009), etc. }\end{array}$ & Three month UK Treasury bill & Datastream \\
\hline Term spread & Positive & Positive & Positive & $\begin{array}{l}\text { Aretz, Bartram, \& Pope (2010), Chordia \& Shivakumar (2002), Lucas, } \\
\text { van Dijk, \& Kloek (2002), Hahn \& Lee (2006), Petkova (2006), etc. }\end{array}$ & $\begin{aligned} \text { Term spread } & =10 \text { year UK government bond yield } \\
& -3 \text { months T-bill yield }\end{aligned}$ & Datastream \\
\hline Credit spread & Negative & Positive & Positive & $\begin{array}{l}\text { Chordia \& Shivakumar (2002), Gulen et al. (2008), Perez-Quiros \& } \\
\text { Timmermann (2000), Hahn \& Lee (2006), Petkova (2006), etc. }\end{array}$ & $\begin{array}{l}\text { Credit spread }=\text { Moody's US BBA yield }-10 \text { year } \\
\text { UK government bond yield }\end{array}$ & Datastream \\
\hline $\begin{array}{l}\text { Money supply } \\
\text { (M2) }\end{array}$ & Positive & Positive & Positive & $\begin{array}{l}\text { Gulen et al. (2008), Perez-Quiros \& Timmermann (2000), Steiner } \\
\text { (2009),etc. }\end{array}$ & $\mathrm{M} 2=\ln \left(\mathrm{M} 2_{\mathrm{t}}\right)-\ln \left(\mathrm{M} 2_{\mathrm{t}-1}\right)$ & Datastream \\
\hline
\end{tabular}


Table 2: Descriptive Statistics of Style Premiums

This table reports the Mean, Standard Deviation, Skewness and Kurtosis of different style based factor returns over the full sample period (1982M07 to 2014M06). Panel A reports the values of overall sample period. Panel $\mathrm{B}$ reports the values over the business cycles. St. Louis fed's recession index is used to define recessions and expansions. The values in the parentheses represent the p-values of Skewness-Kurtosis test for normality.

\begin{tabular}{|c|c|c|c|c|c|}
\hline \multicolumn{6}{|c|}{ Panel A } \\
\hline & & Mean & Standard Deviation & $\begin{array}{l}\text { Coefficient } \\
\text { of Skewness }\end{array}$ & $\begin{array}{l}\text { Coefficient } \\
\text { of Kurtosis }\end{array}$ \\
\hline \multicolumn{2}{|c|}{ SMB } & 0.001232 & 0.031157 & $\begin{array}{l}.1145803 \\
(0.3519)\end{array}$ & $\begin{array}{c}5.129633 * * * * \\
(0.0000)\end{array}$ \\
\hline \multicolumn{2}{|c|}{ HML } & 0.003425 & 0.032387 & $\begin{array}{c}-.5941195^{* * *} * \\
(0.0000)\end{array}$ & $\begin{array}{c}9.573342 * * * \\
(0.0000)\end{array}$ \\
\hline \multicolumn{2}{|c|}{ UMD } & 0.009480 & 0.043678 & $\begin{array}{c}-.9541993 * * * \\
(0.0000)\end{array}$ & $\begin{array}{c}8.635792 \text { *** } \\
(0.0000)\end{array}$ \\
\hline \multicolumn{6}{|c|}{ Panel B } \\
\hline & & Mean & Standard Deviation & $\begin{array}{l}\text { Coefficient } \\
\text { of Skewness }\end{array}$ & $\begin{array}{l}\text { Coefficient } \\
\text { of Kurtosis }\end{array}$ \\
\hline \multirow{3}{*}{ 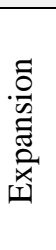 } & SMB & .0033813 & .0298507 & $\begin{array}{l}.1099423 \\
(0.5309)\end{array}$ & $\begin{array}{c}3.909256 \\
(0.0316)\end{array}$ \\
\hline & HML & .0035022 & .033782 & $\begin{array}{c}-1.929098 * * * \\
(0.0000)\end{array}$ & $\begin{array}{c}12.54275^{* * * *} \\
(0.0000)\end{array}$ \\
\hline & UMD & .0092764 & .0377078 & $\begin{array}{c}-.1063751 \\
(0.5442)\end{array}$ & $\begin{array}{c}8.724502 * * * * \\
(0.0000)\end{array}$ \\
\hline \multirow{3}{*}{ 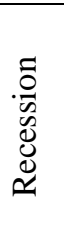 } & SMB & -.0007059 & .0322394 & $\begin{array}{l}.1445545 \\
(0.3879)\end{array}$ & $\begin{array}{c}5.931731 \\
(0.0000)^{* * *}\end{array}$ \\
\hline & HML & .0033599 & .0311644 & $\begin{array}{c}.938617 * * * \\
(0.0000)\end{array}$ & $\begin{array}{c}5.774975^{* * * *} \\
(0.0000)\end{array}$ \\
\hline & UMD & .0096579 & .0485257 & $\begin{array}{c}-1.28699 * * * \\
(0.0000)\end{array}$ & $\begin{array}{c}7.981989 \text { *** } \\
(0.0000)\end{array}$ \\
\hline
\end{tabular}

***Implies the significance at $1 \%$ level of significance, i.e. the hypothesis of normality is rejected. ** Implies the significance at 5\% level of significance, i.e. the hypothesis of normality is rejected. *Implies the significance at $10 \%$ level of significance, i.e. the hypothesis of normality is rejected. 


\section{Table 3: Parameter Estimates of Multiple OLS Regression Model}

This table reports the parameter estimation of multiple regression model. The estimated model is:

$$
\begin{gathered}
r_{i t}=\alpha_{1}+\beta_{i 1} G D P G_{t-1}+\beta_{i 2} I N F_{t-1}+\beta_{i 3} I R_{t-1}+\beta_{i 4} T E R M_{t-1}+\beta_{i 5} C R E D I T_{t-1}+\beta_{i 6} \Delta M_{t-2}+\varepsilon_{i t} ; \\
i=(S M B, H M L, U M D) ; \varepsilon_{i t} \sim N\left(0, \sigma_{i t}^{2}\right)
\end{gathered}
$$

Here $r_{i t}$ is the return of size, value and momentum factors. GDPG is the GDP growth rate, INF is the realized inflation, IR is the short term interest rate, TERM is the term spread, CREDIT is the credit spread and $\triangle \mathrm{M}$ is the growth of money supply.

\begin{tabular}{cccc}
\hline & SMB & HML & UMD \\
\hline$\alpha_{1}$ & -0.003718 & -0.010698 & 0.013285 \\
& $(0.5534)$ & $(0.1112)$ & $(0.1448)$ \\
\hline$G D P G_{t-1}$ & $2.972630^{* *}$ & 1.901194 & 1.818247 \\
& $(0.0153)$ & $(0.1457)$ & $(0.3048)$ \\
\hline$I N F_{t-1}$ & $0.385759^{* *}$ & 0.119489 & -0.179156 \\
& $(0.0122)$ & $(0.4659)$ & $(0.4205)$ \\
\hline$I R_{t-1}$ & -0.848198 & $1.698680^{* *}$ & -0.379323 \\
& $(0.2940)$ & $(0.0497)$ & $(0.7461)$ \\
\hline$T E R M_{t-1}$ & -0.080550 & 0.085839 & -0.111149 \\
& $(0.5733)$ & $(0.5745)$ & $(0.5921)$ \\
\hline$C R E D I T_{t-1}$ & $0.250738^{*}$ & $0.329427 * *$ & -0.135733 \\
& $(0.0934)$ & $(0.0394)$ & $(0.5307)$ \\
\hline$\Delta M_{t-2}$ & $0.576761 * * *$ & -0.150828 & 0.256228 \\
& $(0.0038)$ & $(0.4771)$ & $(0.3735)$ \\
\hline Standard Error & 0.030222 & 0.032308 & 0.043843 \\
\hline R-Squared & 0.076441 & 0.018950 & 0.012809 \\
\hline
\end{tabular}




\section{Table 4: Parameter estimation of Markov Switching Model}

The estimated two-state Markov switching model is:

$$
\begin{gathered}
r_{i t}=\alpha_{1}+\beta_{i 1, s_{t}} G D P G_{t-1}+\beta_{i 2, s_{t}} I N F_{t-1}+\beta_{i 3, s_{t}} I R_{t-1}+\beta_{i 4, s_{t}} T E R M_{t-1}+\beta_{i 5, s_{t}} C R E D I T_{t-1}+\beta_{i b, s_{t}} \Delta M_{t-2}+\varepsilon_{i t} \\
i=(S M B, H M L, U M D) ; \quad \varepsilon_{i t} \sim N\left(0, \sigma_{i t}^{2}\right), \quad S_{t}=\{1,2\} \\
P_{11}=P\left(s_{t}=1 \mid s_{t-1}=1, z_{t-1}\right)=\Phi\left(\pi_{0}+\pi_{1} C L I_{t-2}\right), P_{12}=1-P_{11} \\
P_{22}=P\left(s_{t}=2 \mid s_{t-1}=2, z_{t-1}\right)=\Phi\left(\pi_{0}+\pi_{2} C L I_{t-2}\right), P_{21}=1-P_{22}
\end{gathered}
$$

Here $r_{i t}$ is the return of size, value and momentum factors. GDPG is the GDP growth rate, INF is the realized

\begin{tabular}{|c|c|c|c|c|}
\hline & & SMB & HML & UMD \\
\hline \multirow{8}{*}{ 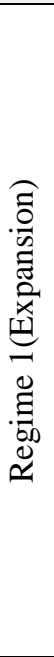 } & $\alpha_{1}$ & $\begin{array}{c}0.003474 \\
(0.5550)\end{array}$ & $\begin{array}{c}-0.017747 * * * \\
(0.0006)\end{array}$ & $\begin{array}{c}0.167793 * * * \\
(0.0058)\end{array}$ \\
\hline & $G D P G_{t-1}$ & $\begin{array}{l}2.344566^{*} \\
(0.0844)\end{array}$ & $\begin{array}{l}3.520900 * * * \\
(0.0004)\end{array}$ & $\begin{array}{c}-4.712032 \\
(0.2992)\end{array}$ \\
\hline & $I N F_{t-1}$ & $\begin{array}{c}0.369968 * * \\
(0.0121)\end{array}$ & $\begin{array}{c}0.120493 \\
(0.3541)\end{array}$ & $\begin{array}{c}0.348204 \\
(0.6243)\end{array}$ \\
\hline & $I R_{t-1}$ & $\begin{array}{c}-1.192405 \\
(0.1103)\end{array}$ & $\begin{array}{c}2.506955^{* * *} \\
(0.0001)\end{array}$ & $\begin{array}{c}-23.82852 * * \\
(0.0122)\end{array}$ \\
\hline & $T E R M_{t-1}$ & $\begin{array}{c}-0.231651^{*} \\
(0.0996)\end{array}$ & $\begin{array}{c}0.273211^{* *} \\
(0.0181)\end{array}$ & $\begin{array}{c}-1.871451 \\
(0.1256)\end{array}$ \\
\hline & $C R E D I T_{t-1}$ & $\begin{array}{c}0.205820 \\
(0.1418)\end{array}$ & $\begin{array}{c}0.298536^{* * *} \\
(0.0217)\end{array}$ & $\begin{array}{c}-6.290640 * * * \\
(0.0000)\end{array}$ \\
\hline & $\Delta M_{t-2}$ & $\begin{array}{c}0.196170 \\
(0.2981)\end{array}$ & $\begin{array}{l}0.085135 \\
(0.5902)\end{array}$ & $\begin{array}{l}1.167759 \\
(0.1607)\end{array}$ \\
\hline & $\begin{array}{c}\text { Conditional Standard } \\
\text { Deviation }\end{array}$ & 0.041940 & 0.011578 & 0.020489 \\
\hline \multirow{8}{*}{  } & $\bar{~} \alpha_{1}$ & $\begin{array}{c}-0.259131 * * * \\
(0.0000)\end{array}$ & $\begin{array}{c}-0.240148^{* * * *} \\
(0.0000)\end{array}$ & $\begin{array}{c}0.022916 * * * \\
(0.0020)\end{array}$ \\
\hline & $G D P G_{t-1}$ & $\begin{array}{c}22.46944 * * * \\
(0.0000)\end{array}$ & $\begin{array}{c}-66.49195^{* * * *} \\
(0.0000)\end{array}$ & $\begin{array}{c}-1.834958 \\
(0.2580)\end{array}$ \\
\hline & $I N F_{t-1}$ & $\begin{array}{c}1.554869 * * \\
(0.0165)\end{array}$ & $\begin{array}{l}0.408614 \\
(0.5143)\end{array}$ & $\begin{array}{c}0.094883 \\
(0.5975)\end{array}$ \\
\hline & $I R_{t-1}$ & $\begin{array}{c}26.23414 * * * \\
(0.0017)\end{array}$ & $\begin{array}{c}17.55085^{* * *} \\
(0.0000)\end{array}$ & $\begin{array}{c}-1.827687 * * \\
(0.0493)\end{array}$ \\
\hline & $T E R M_{t-1}$ & $\begin{array}{l}2.938451 * * * \\
(0.0004)\end{array}$ & $\begin{array}{c}-8.521932 * * * \\
(0.0000)\end{array}$ & $\begin{array}{c}-0.495384 * * * \\
(0.0041)\end{array}$ \\
\hline & $C R E D I T_{t-1}$ & $\begin{array}{c}5.151615^{* * * *} \\
(0.0000)\end{array}$ & $\begin{array}{c}6.749098 * * * \\
(0.0000)\end{array}$ & $\begin{array}{c}0.426099 * * \\
(0.0137)\end{array}$ \\
\hline & $\Delta M_{t-2}$ & $\begin{array}{c}4.461694 * * * \\
(0.0000)\end{array}$ & $\begin{array}{c}-3.170360 * * * \\
(0.0000)\end{array}$ & $\begin{array}{c}0.054154 \\
(0.7741)\end{array}$ \\
\hline & $\begin{array}{c}\text { Conditional Standard } \\
\text { Deviation }\end{array}$ & 0.188605 & 0.226901 & 0.053830 \\
\hline
\end{tabular}
inflation, and IR is the short term interest rate. TERM is the term spread, CREDIT is the credit spread and $\triangle \mathrm{M}$ is the growth of money supply; and CLI is the OECD's Composite Leading Indicator.The values in the parentheses represent the p-values.

*** Implies the significance at $1 \%$ level of significance.

** Implies the significance at 5\% level of significance.

* Implies the significance at $10 \%$ level of significance. 


\section{Wald Test}

This table reports the Wald test's outcome for the hypothesis testing of switches in the intercept and switches in the slope.

The test statistics for the Wald test are:

$$
\begin{gathered}
\text { For, } H_{0}: \alpha_{i 1}=\alpha_{i 2} ; \frac{\left(\widehat{\alpha}_{1}-\widehat{\alpha}_{2}\right)^{2}}{\operatorname{Var}\left(\widehat{\alpha}_{1}\right)+\operatorname{Var}\left(\widehat{\alpha}_{1}\right)-2 \operatorname{cov}\left(\widehat{\alpha}_{1}, \widehat{\alpha}_{2}\right)} \approx \chi^{2}(1) ; i=S M B, H M L, U M D \\
\text { For } H_{0}: \beta_{j 1}=\beta_{j 2} ; \frac{\left(\widehat{\beta}_{1}-\widehat{\beta}_{2}\right)^{2}}{\operatorname{Var}\left(\widehat{\beta}_{1}\right)+\operatorname{Var}\left(\widehat{\beta}_{1}\right)-2 \operatorname{cov}\left(\widehat{\beta}_{1}, \widehat{\beta}_{2}\right)} \approx \chi^{2}(6) ; J=2,3,4,5,6,7
\end{gathered}
$$

\begin{tabular}{c|c|c|c}
\hline Hypothesis & $\begin{array}{c}\text { SMB } \\
\text { (Chi-Square) }\end{array}$ & $\begin{array}{c}\text { HML } \\
\text { (Chi-Square) }\end{array}$ & $\begin{array}{c}\text { UMD } \\
\text { (Chi-Square) }\end{array}$ \\
\hline Switches in the Intercept & & & \\
$H_{01}: \alpha_{S M B,\left(s_{t}=1\right)}=\alpha_{S M B,\left(s_{t}=2\right)}$ & $21.65018^{* * *}$ & $41.75555^{* * *}$ & $(0.0000)$ \\
$H_{02}: \alpha_{H M L,\left(s_{t}=1\right)}=\alpha_{H M L,\left(s_{t}=2\right)}$ & $(0.0000)$ & & $5.689131^{* *}$ \\
$H_{03}: \alpha_{U M D,\left(s_{t}=1\right)}=\alpha_{U M D,\left(s_{t}=2\right)}$ & & & \\
& & & \\
Switches in the Slope & & $315.0171)$ \\
$H_{01}: \beta_{S M B, j,\left(s_{t}=1\right)}=\beta_{S M B, j,\left(s_{t}=2\right)}$ & & $(0.0000)$ & $79.42191 * * *$ \\
$H_{02}: \beta_{H M L, j,\left(s_{t}=1\right)}=\beta_{H M L, j,\left(s_{t}=2\right)}$ & $92.26251^{* * *}$ & $(0.0000)$ \\
$H_{03}: \beta_{U M D, j,\left(s_{t}=1\right)}=\beta_{U M D, j,\left(s_{t}=2\right)}$ & $(0.0001)$ & & \\
$j=2,3,4,5,6,7$ & & &
\end{tabular}

*** Implies the significance at $1 \%$ level of significance.

** Implies the significance at $5 \%$ level of significance.

* Implies the significance at $10 \%$ level of significance. 


\section{Table 6: Likelihood Ratio Test for Redundant Variable}

This table reports the likelihood ratio test for the redundant variables to identify the significance of the regressors in the models. The estimated two-state Markov switching model is:

$$
\begin{gathered}
r_{i t}=\alpha_{1}+\beta_{i 1, s_{t}} G D P G_{t-1}+\beta_{i 2, s_{t}} I N F_{t-1}+\beta_{i 3, s_{t}} I R_{t-1}+\beta_{i 4, s_{t}} T E R M_{t-1}+\beta_{i 5, s_{t}} C_{R E D I T_{t-1}}+\beta_{i 6, s_{t}} \Delta M_{t-2}+\varepsilon_{i t} ; \\
i=(S M B, H M L, U M D) ; \quad \varepsilon_{i t} \sim N\left(0, \sigma_{i t}^{2}\right), \quad S_{t}=\{1,2\} \\
P_{11}=P\left(s_{t}=1 \mid s_{t-1}=1, z_{t-1}\right)=\Phi\left(\pi_{0}+\pi_{1} C L I_{t-2}\right), P_{12}=1-P_{11}=P\left(s_{t}=1 \mid s_{t-1}=2, z_{t-1}\right) \\
P_{22}=P\left(s_{t}=2 \mid s_{t-1}=2, z_{t-1}\right)=\Phi\left(\pi_{0}+\pi_{2} C L I_{t-2}\right), P_{21}=1-P_{22}=P\left(s_{t}=2 \mid s_{t-1}=1, z_{t-1}\right)
\end{gathered}
$$

Here $r_{i t}$ is the return of size, value and momentum factors. GDPG is the GDP growth rate, INF is the realized

\begin{tabular}{|c|c|c|c|}
\hline Likelihood Ratio & SMB & HML & UMD \\
\hline Unrestricted Log Likelihood & 828.1365 & 859.6611 & 721.5690 \\
\hline $\begin{array}{c}\text { Log Likelihood with } \\
\beta_{i 1}=0, \\
i=S M B, H M L, U M D\end{array}$ & $\begin{array}{c}818.5313^{* * * *} \\
(0.0000)\end{array}$ & $\begin{array}{c}841.1312 * * * \\
\quad(0.0000)\end{array}$ & $\begin{array}{c}720.7072 * \\
(0.1892)\end{array}$ \\
\hline $\begin{array}{c}\text { Log Likelihood with } \\
\beta_{i 2}=0, \\
i=S M B, H M L, U M D\end{array}$ & $\begin{array}{c}814.5014^{* * *} * \\
\quad(0.0000)\end{array}$ & $\begin{array}{c}858.9896 \\
(0.2465)\end{array}$ & $\begin{array}{l}721.3299 \\
(0.4892)\end{array}$ \\
\hline $\begin{array}{c}\text { Log Likelihood with } \\
\beta_{i 3}=0, \\
i=S M B, H M L, U M D\end{array}$ & $\begin{array}{c}818.0224 * * * \\
(0.0069)\end{array}$ & $\begin{array}{c}846.2138 * * * \\
(0.0000)\end{array}$ & $\begin{array}{c}719.5768 * * \\
(0.0459)\end{array}$ \\
\hline $\begin{array}{c}\text { Log Likelihood with } \\
\beta_{i 4}=0, \\
i=S M B, H M L, U M D\end{array}$ & $\begin{array}{c}809.9817 * * * \\
(0.0659)\end{array}$ & $\begin{array}{c}853.3821 * * * \\
\quad(0.0000)\end{array}$ & $\begin{array}{c}717.4515^{* * * *} \\
(0.0041)\end{array}$ \\
\hline $\begin{array}{c}\text { Log Likelihood with } \\
\beta_{i 5}=0, \\
i=S M B, H M L, U M D\end{array}$ & $\begin{array}{c}812.7886^{* * * *} \\
(0.0000)\end{array}$ & $\begin{array}{c}846.8765^{* * *} * \\
(0.0001)\end{array}$ & $\begin{array}{c}709.2969 * * * \\
(0.0000)\end{array}$ \\
\hline $\begin{array}{c}\text { Log Likelihood with } \\
\beta_{i 6}=0, \\
i=S M B, H M L, U M D\end{array}$ & $\begin{array}{c}814.8402 * * * \\
\quad(0.0000)\end{array}$ & $\begin{array}{c}841.0220 * * * \\
(0.0000)\end{array}$ & $\begin{array}{l}720.3951 \\
(0.1255)\end{array}$ \\
\hline
\end{tabular}
inflation, and IR is the short term interest rate. TERM is the term spread, CREDIT is the credit spread and $\triangle \mathrm{M}$ is the growth of money supply; and CLI is the OECD's Composite Leading Indicator. The p-value of likelihood ratio test indicates the probability of the insignificance of corresponding regressor.

\footnotetext{
*** Implies the significance at $1 \%$ level of significance.

** Implies the significance at 5\% level of significance.

* Implies the significance at $10 \%$ level of significance.
} 


\section{Table 7: Parameter Estimation of Markov Switching Model: Using IP Index as an}

\section{Alternative Information Variable in Modelling Transitions Probabilities}

$$
\begin{gathered}
\text { The estimated two-state Markov switching model is: } \\
r_{t}=\alpha_{1}+\beta_{i 1, s_{t}} G D P G_{t-1}+\beta_{i 2, s_{t}} I N F_{t-1}+\beta_{i 3, s_{t}} I R_{t-1}+\beta_{i 4, s_{t}} T E R M_{t-1}+\beta_{i 5, s_{t}} C R E D I T_{t-1}+\beta_{i 6, s_{t}} \Delta M_{t-2}+\varepsilon_{i t} ; \\
i=(S M B, H M L, U M D) ; \quad \varepsilon_{i t} \sim N\left(0, \sigma_{i t}^{2}\right), \quad S_{t}=\{1,2\} \\
P_{11}=P\left(s_{t}=1 \mid s_{t-1}=1, z_{t-1}\right)=\Phi\left(\pi_{0}+\pi_{1} I P_{t-1}\right), P_{12}=1-P_{11} \\
P_{22}=P\left(s_{t}=2 \mid s_{t-1}=2, z_{t-1}\right)=\Phi\left(\pi_{0}+\pi_{2} I P_{t-1}\right), P_{21}=1-P_{22}
\end{gathered}
$$

Here $r_{i t}$ is the return of size, value and momentum factors, GDPG is the GDP growth rate, INF is the realized

\begin{tabular}{|c|c|c|c|c|}
\hline & & SMB & HML & UMD \\
\hline \multirow{8}{*}{ 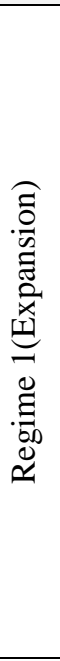 } & $\alpha_{1}$ & $\begin{array}{l}0.002317 \\
(0.6855)\end{array}$ & $\begin{array}{c}-0.017625 * * * * \\
(0.0007)\end{array}$ & $\begin{array}{c}0.018694 * * * \\
(0.0097)\end{array}$ \\
\hline & $G D P G_{t-1}$ & $\begin{array}{l}1.463355 \\
(0.2597)\end{array}$ & $\begin{array}{c}3.502783^{* * * *} \\
(0.0004)\end{array}$ & $\begin{array}{c}-1.164752 \\
(0.4037)\end{array}$ \\
\hline & $I N F_{t-1}$ & $\begin{array}{c}0.453465^{* * * *} \\
(0.0027)\end{array}$ & $\begin{array}{c}0.143064 \\
(0.2762) \\
\end{array}$ & $\begin{array}{c}0.043448 \\
(0.7206) \\
\end{array}$ \\
\hline & $I R_{t-1}$ & $\begin{array}{c}-1.212458^{*} \\
(0.0984) \\
\end{array}$ & $\begin{array}{c}2.514588^{* * * *} \\
(0.0001)\end{array}$ & $\begin{array}{c}-1.367553 \\
(0.1389) \\
\end{array}$ \\
\hline & $T E R M_{t-1}$ & $\begin{array}{c}-0.240752^{*} \\
(0.1039) \\
\end{array}$ & $\begin{array}{c}0.266736^{* * *} \\
(0.0214) \\
\end{array}$ & $\begin{array}{c}-0.380272 * * \\
(0.0158) \\
\end{array}$ \\
\hline & CREDIT $_{t-1}$ & $\begin{array}{c}0.291675^{* *} \\
(0.0363)\end{array}$ & $\begin{array}{l}0.298651^{* *} \\
(0.0230)\end{array}$ & $\begin{array}{c}0.428205^{* *} \\
(0.0110)\end{array}$ \\
\hline & $\Delta M_{t-2}$ & $\begin{array}{l}0.234085 \\
(0.2265)\end{array}$ & $\begin{array}{l}0.073415 \\
(0.6149)\end{array}$ & $\begin{array}{l}0.102880 \\
(0.6185)\end{array}$ \\
\hline & $\begin{array}{c}\text { Conditional Standard } \\
\text { Deviation } \\
\end{array}$ & 0.008518 & 0.001460 & 0.027747 \\
\hline \multirow{8}{*}{ 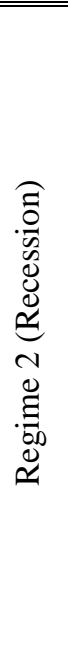 } & $\alpha_{1}$ & $\begin{array}{l}-0.144048 * * \\
(0.0128)\end{array}$ & $\begin{array}{l}-0.234666 * * * \\
(0.0000)\end{array}$ & $\begin{array}{c}0.069190^{*} \\
(0.0575)\end{array}$ \\
\hline & $G D P G_{t-1}$ & $\begin{array}{c}16.43552^{* * * *} \\
(0.0000)\end{array}$ & $\begin{array}{c}-66.50175^{* * * *} \\
(0.0000)\end{array}$ & $\begin{array}{c}-4.946730 \\
(0.3071)\end{array}$ \\
\hline & $I N F_{t-1}$ & $\begin{array}{c}-0.110192 \\
(0.8378)\end{array}$ & $\begin{array}{l}0.444140 \\
(0.4909)\end{array}$ & $\begin{array}{l}0.704047 \\
(0.4701)\end{array}$ \\
\hline & $I R_{t-1}$ & $\begin{array}{l}13.29070 \\
(0.1417)\end{array}$ & $\begin{array}{c}16.44003^{* * * *} \\
(0.0001)\end{array}$ & $\begin{array}{c}-0.040574 \\
(0.8089)\end{array}$ \\
\hline & $T E R M_{t-1}$ & $\begin{array}{c}2.184715 * * \\
(0.0491) \\
\end{array}$ & $\begin{array}{c}-8.454087 * * * * \\
(0.0000)\end{array}$ & $\begin{array}{c}1.652218^{* * *} \\
(0.0537) \\
\end{array}$ \\
\hline & CREDIT $_{t-1}$ & $\begin{array}{l}2.259204 * * \\
(0.0329)\end{array}$ & $\begin{array}{c}6.746357^{* * * *} \\
(0.0000)\end{array}$ & $\begin{array}{c}-6.892137 * * * \\
(0.0000)\end{array}$ \\
\hline & $\Delta M_{t-2}$ & $\begin{array}{c}4.042608^{* * * *} \\
(0.0000)\end{array}$ & $\begin{array}{c}-3.133290 * * * * \\
(0.0000)\end{array}$ & $\begin{array}{c}2.277822 * * * * \\
(0.0075)\end{array}$ \\
\hline & $\begin{array}{l}\text { Conditional Standard } \\
\text { Deviation }\end{array}$ & 0.143565 & 0.190502 & 0.251312 \\
\hline
\end{tabular}
inflation, and IR is the short term interest rate. TERM is the term spread, CREDIT is the credit spread and $\triangle \mathrm{M}$ is the growth of money supply; and $I P$ is the change in the Industrial Production index of UK. The values in the parentheses represent the p-values.

\footnotetext{
*** Implies the significance at $1 \%$ level of significance.

** Implies the significance at 5\% level of significance.

* Implies the significance at $10 \%$ level of significance
} 
Table 8: Trading Strategy results for eight portfolios (Jan 2008 to Dec 2014)

Trading results are based on the monthly switching between the eight style portfolios (namely: small growth (SL), small value (SH), big growth (BL), big value (BH), small losers (SD), small winners (SU), big losers (BD) and big winners (BU)) and T-bills. A long position in the relevant style portfolio is taken if its return from the recursively predicted by the model is positive, otherwise we invest in one month T-Bill. The buy-and-hold strategy represents the investment in the corresponding style portfolio over the trading period. Annualized mean returns, standard deviations and Sharpe ratios are reported for each style portfolio switching strategy and its buy-and-hold benchmark. The number of switches denotes number of times we switch between the given style portfolio and one month T-bill during the trading period. Break-even transaction costs are maximum costs an investor would pay per switch that equalise the Sharpe ratio of the switching strategy and that of the buy-and-hold. Negative (zero (0.0)) break-even transaction costs imply the Sharpe ratio of the switching strategy was lower (equal to) the Sharpe of the buy-and-hold. Bold denotes the breakeven transaction costs per switch that are large enough to imply the switching strategy is feasible. Panel A reports findings for Small size portfolios and their subgroups while Panel B for large cap portfolios and their subgroups. All results are reported for full out-of-sample period, expansions and recessions separately.

\begin{tabular}{|c|c|c|c|c|c|c|c|c|}
\hline \multirow[t]{2}{*}{ PANEL A } & \multicolumn{2}{|c|}{$\begin{array}{c}\text { Small cap with } \\
\text { low book-to-market (SL) }\end{array}$} & \multicolumn{2}{|c|}{$\begin{array}{c}\text { Small firms with } \\
\text { high book-to-market (SH) }\end{array}$} & \multicolumn{2}{|c|}{$\begin{array}{c}\text { Small Firms with down } \\
\text { momentum (SD) }\end{array}$} & \multicolumn{2}{|c|}{$\begin{array}{l}\text { Small Firms with up momentum } \\
\text { (SU) }\end{array}$} \\
\hline & $\begin{array}{c}\text { Buy and } \\
\text { Hold }\end{array}$ & $\begin{array}{l}\text { Switching } \\
\text { Portfolio }\end{array}$ & $\begin{array}{c}\text { Buy and } \\
\text { Hold }\end{array}$ & $\begin{array}{c}\text { Switching } \\
\text { Portfolio }\end{array}$ & $\begin{array}{c}\text { Buy and } \\
\text { Hold }\end{array}$ & $\begin{array}{l}\text { Switching } \\
\text { Portfolio }\end{array}$ & $\begin{array}{c}\text { Buy and } \\
\text { Hold }\end{array}$ & $\begin{array}{l}\text { Switching } \\
\text { Portfolio }\end{array}$ \\
\hline \multicolumn{9}{|l|}{ Full period } \\
\hline Mean Return & 12.85 & 14.71 & 8.53 & 11.60 & 7.28 & 8.56 & 19.71 & 19.82 \\
\hline Std. Dev. & 17.60 & 17.01 & 24.06 & 22.52 & 29.62 & 25.14 & 18.41 & 18.40 \\
\hline Sharpe Ratio & 0.67 & 0.80 & 0.31 & 0.47 & 0.21 & 0.30 & 1.01 & 1.02 \\
\hline No. of Switches & & 5 & & 11 & & 13 & - & \\
\hline Break Even TC & & 278.56 BPS & & 196.66 BPS & & 108.50 BPS & - & 18.55 BPS \\
\hline \multicolumn{9}{|l|}{ Expansions } \\
\hline Mean Return & 22.51 & 22.51 & 19.07 & 16.15 & 11.99 & 9.32 & 31.76 & 31.76 \\
\hline Std. Dev. & 15.73 & 15.73 & 21.29 & 20.72 & 21.62 & 17.56 & 17.97 & 19.13 \\
\hline Sharpe Ratio & 0.78 & 0.78 & 0.50 & 0.43 & 0.31 & 0.29 & 0.94 & 0.94 \\
\hline No. of Switches & & 0 & & 4 & & 5 & - & 0 \\
\hline Break Even TC & - & 0.00 & - & Negative & & Negative & - & 0.00 \\
\hline \multicolumn{9}{|l|}{ Recessions } \\
\hline Mean Return & 8.02 & 10.81 & 3.27 & 9.33 & 4.93 & 8.18 & 13.69 & 13.85 \\
\hline Std. Dev. & 18.45 & 17.66 & 25.40 & 23.54 & 33.07 & 28.34 & 18.55 & 18354 \\
\hline Sharpe Ratio & 0.30 & 0.44 & 0.06 & 0.28 & 0.09 & 0.20 & 0.54 & 0.55 \\
\hline No. of Switches & - & 5 & - & 7 & & 8 & - & 3 \\
\hline Break Even TC & - & 258.12 BPS & - & 383.96 BPS & & 199.12 BPS & - & 22.65 BPS \\
\hline
\end{tabular}




\begin{tabular}{|c|c|c|c|c|c|c|c|c|}
\hline \multirow[t]{2}{*}{ PANEL B } & \multicolumn{2}{|c|}{$\begin{array}{c}\text { Big firms with } \\
\text { low book-to-market (BL) }\end{array}$} & \multicolumn{2}{|c|}{$\begin{array}{c}\text { Big firms with } \\
\text { high book-to-market }(\mathrm{BH})\end{array}$} & \multicolumn{2}{|c|}{$\begin{array}{l}\text { Big Firms with down } \\
\text { momentum (BD) }\end{array}$} & \multicolumn{2}{|c|}{$\begin{array}{l}\text { Big Firms with up } \\
\text { momentum (BU) }\end{array}$} \\
\hline & $\begin{array}{l}\text { Buy and } \\
\text { Hold }\end{array}$ & $\begin{array}{l}\text { Switching } \\
\text { Portfolio }\end{array}$ & $\begin{array}{c}\text { Buy and } \\
\text { Hold }\end{array}$ & $\begin{array}{l}\text { Switching } \\
\text { Portfolio }\end{array}$ & $\begin{array}{c}\text { Buy and } \\
\text { Hold }\end{array}$ & $\begin{array}{l}\text { Switching } \\
\text { Portfolio }\end{array}$ & $\begin{array}{l}\text { Buy and } \\
\text { Hold }\end{array}$ & $\begin{array}{l}\text { Switching } \\
\text { Portfolio }\end{array}$ \\
\hline Full period & & & & & & & & \\
\hline Mean Return & 10.41 & -1.04 & 5.96 & 5.27 & 4.50 & 4.93 & 10.28 & 10.28 \\
\hline Std. Dev. & 12.59 & 7.38 & 17.78 & 16.23 & 23.81 & 23.78 & 19.85 & 19.85 \\
\hline Sharpe Ratio & 0.74 & -0.27 & 0.28 & 0.26 & 0.15 & 0.16 & 0.46 & 0.46 \\
\hline No. of Switches & & 6 & & 9 & - & 3 & - & 1 \\
\hline Break Even TC & & Negative & & Negative & - & 68.85 BPS & - & 0.00 \\
\hline Expansions & & & & & & & & \\
\hline Mean Return & 20.22 & 3.10 & 20.52 & 20.66 & 19.13 & 19.13 & 24.16 & 24.16 \\
\hline Std. Dev. & 10.80 & 3.84 & 16.86 & 16.84 & 18.03 & 18.03 & 21.21 & 21.21 \\
\hline Sharpe Ratio & 0.98 & 0.39 & 0.67 & 0.67 & 0.59 & 0.59 & 0.63 & 0.63 \\
\hline No. of Switches & - & 2 & & 2 & - & 0 & - & 0 \\
\hline Break Even TC & - & Negative & & Negative & - & 0.00 & - & 0.00 \\
\hline Recessions & & & & & & & & \\
\hline Mean Return & 5.50 & -3.11 & -1.32 & -2.42 & -2.81 & -2.18 & 3.35 & 3.35 \\
\hline Std. Dev. & 13.27 & 8.60 & 18.02 & 15.61 & 26.13 & 26.11 & 19.03 & 19.03 \\
\hline Sharpe Ratio & 0.26 & -0.41 & -0.12 & -0.19 & -0.13 & -0.11 & 0.09 & 0.09 \\
\hline No. of Switches & - & 4 & - & 7 & - & 3 & - & 1 \\
\hline Break Even TC & - & Negative & - & Negative & - & 108.28 BPS & - & 0.00 \\
\hline
\end{tabular}


